\title{
Blunt Instruments: A Cautionary Note on Establishing the Causes of Economic Growth
}

\section{Samuel Bazzi and Michael A. Clemens}

\section{Abstract}

Concern has intensifed in recent years that many instrumental variables used in widely cited growth regressions may be invalid, weak, or both. Attempts to remedy this general problem remain inadequate. We demonstrate that a range of published growth regressions may contain spurious results because of hidden problems with the instrumental variables they use. We urge several steps to surpass these difficulties: grounding of growth regressions in slightly more generalized theoretical models, deployment of the latest methods for estimating sensitivity to violations of exclusion restrictions, opening the "black box" of GMM with supportive evidence of instrument strength, and utilization of weak-instrument robust tests and estimators.

JEL Codes: F35, C12, O4 


\title{
Blunt Instruments: A Cautionary Note on Establishing the Causes of Economic Growth
}

\author{
Samuel Bazzi \\ Dept. of Economics \\ University of California, San Diego. \\ Michael A. Clemens \\ Center for Global Development \\ Washington, D.C.
}

May 2009 (Revised July 2010)

We thank William Easterly, Aart Kraay, Paul Niehaus, Valerie Ramey, James Rauch, and David Roodman for helpful discussions. We thank the following for graciously providing access to data and programs: William Hauk, Arvind Subramanian, Jason Hwang, Sarah Voitchovsky, and Marla Ripoll. Any errors that remain are exclusively ours. Nothing herein necessarily represents the views of the Center for Global Development, its board, or its funders.

CGD is grateful for contributions from the William and Flora Hewlett Foundation in support of this work.

Samuel Bazzi and Michael Clemens. 2009. "Blunt Instruments: On Establishing the Causes of Economic Growth.” CGD Working Paper 171. Washington, D.C.: Center for Global Development.http://www.cgdev.org/content/publications/detail/1422132/

Center for Global Development 1800 Massachusetts Ave., NW Washington, DC 20036

202.416.4000

(f) 202.416 .4050

www.cgdev.org
The Center for Global Development is an independent, nonprofit policy research organization dedicated to reducing global poverty and inequality and to making globalization work for the poor. Use and dissemination of this Working Paper is encouraged; however, reproduced copies may not be used for commercial purposes. Further usage is permitted under the terms of the Creative Commons License.

The views expressed in this paper are those of the author and should not be attributed to the board of directors or funders of the Center for Global Development. 


\section{Introduction}

One of the great projects of economic research is to establish the causes of growth. Separating causes from correlates, however, is difficult. Many researchers have recently addressed this difficulty by deploying instrumental variables in cross-country datasets. This can help to identify causes of growth if the instruments do not materially affect growth through channels other than the variable of interest (the instruments are "valid") and if the instruments correlate well with the variable of interest (the instruments are "strong"). Unfortunately, for reasons not always transparent in published studies, these instruments can be invalid, weak, or both.

In this paper, we examine problems of instrument validity and strength in several growth papers recently published in general-interest and top field journals - not to single out those papers, but to concretely illustrate a general phenomenon that goes well beyond them. First, we discuss how an instrument that is plausibly valid when used in a single setting can be shown invalid by its use in additional settings. Second, we offer evidence that unacknowledged weak instruments may generate spurious findings in important applications, especially those using the popular Generalized Method of Moments (GMM) dynamic panel estimators. This evidence consists of simulation exercises and simple diagnostics on the data underlying published studies.

Our contribution is to show that these problems can have important consequences in real published work, and to suggest remedies. We advocate four ways that growth researchers can surmount these difficulties: by basing instrumental variable regressions on theory sufficiently general to comprise other published results with the same instrument, by using the latest methods to probe sensitivity to violations of the exclusion restriction, by opening the "black box" of GMM with complementary methods to assess instrument strength, and by deploying weak instrument robust testing procedures and estimators. We discuss each in detail below.

\section{Instrumentation and its discontents}

The wave of international growth empirics begun by Baumol (1986) and advanced by Barro (1991) inspired early skepticism even from its own contributors:

"Using these regressions to decide how to foster growth is ... most likely a hopeless task. Simultaneity, multicollinearity, and limited degrees of freedom are important 
practical problems for anyone trying to draw inferences from international data. Policymakers who want to promote growth would not go far wrong ignoring most of the vast literature reporting growth regressions." (Mankiw, 1995).

Researchers thereafter began to address many of these problems. They became more assiduous in checking the robustness of results to the choice of regression specification (Sala-i-Martin, 1997; Salai-Martin, Doppelhofer and Miller, 2004). They explored concerns about parameter heterogeneity, measurement error, and influential observations (Temple, 1999; Hauk and Wacziarg, 2009). They expanded their samples as the succession of years and improvements in information technology have brought a flood of new data (Bosworth and Collins, 2003; Easterly, Levine and Roodman, 2004).

Beyond this, researchers have taken greater care in identifying the causal portion of the relationships they observe across countries. Architects of growth regressions published in top journals have used cross-country instrumental variables for governance quality, ${ }^{1}$ trade, ${ }^{2}$ and foreign aid, ${ }^{3}$ among several other growth determinants. New developments in econometrics have assisted this search for better identification - especially the advent of sophisticated dynamic panel Generalized Method of Moments (GMM) estimators, which entered the growth literature with Caselli, Esquivel and Lefort (1996).

But in parallel with these welcome efforts, the economics literature in general has showed increasing concern with the strength and validity of instrumental variables in practice (surveyed by Murray (2006)). Close investigations have suggested that many cross-country instruments may be weak, invalid, or both, in widely-cited studies on the growth effects of governance or trade (e.g. Rodríguez and Rodrik, 2001; Brock and Durlauf, 2001; Dollar and Kraay, 2003; Glaeser, La Porta, López-de-Silanes, and Shleifer, 2004; Albouy, 2008; Kraay, 2008). Notwithstanding the popularity of instrumental variables in recent growth empirics, Durlauf, Johnson, and Temple (2005) conclude that "the belief that it is easy to identify valid instrumental variables in the growth context is deeply mistaken. We regard many applications of instrumental variable procedures in the empirical growth

\footnotetext{
${ }^{1}$ These include cross-country instrumental variables based on exogenous deaths of national leaders while in office (Jones and Olken, 2005), colonial-era settler mortality (Acemoğlu, Johnson and Robinson, 2001), a Soviet-era survey of ethnolinguistic fractionalization (Mauro, 1995), distance from the equator (Hall and Jones, 1999), and Pacific-basin wind patterns (Feyrer and Sacerdote, 2009).

${ }^{2}$ These include cross-country instruments based on geographic characteristics (Frankel and Romer, 1999; Frankel and Rose, 2002).

${ }^{3}$ These include cross-country instruments based on political ties, economic policies, and country size (Burnside and Dollar, 2000; Angeles and Neanidis, 2009). Boone (1996) also uses instruments based on political ties and country size in related work examining the impact of aid on investment growth.
} 
literature to be undermined by the failure to address properly the question of whether these instruments are valid". Acemoğlu (2010) decries the widespread use of "instruments without theory" and Hauk and Wacziarg (2009) see "unjustified claims of causality" as a prominent feature of growth empirics.

Our paper extends a growing body of research aimed at identifying econometric best practice in growth empirics. First, we provide concrete evidence on ways in which published studies can collectively invalidate the instruments used in each study separately. Second, building on Bun and Windmeijer (2010) and Hauk and Wacziarg (2009), we indicate and suggest remedies for different sources of bias in the most popular estimator deployed in panel data growth econometrics, the system GMM estimator of Blundell and Bond (1998). Through simple diagnostic tests and a Monte Carlo simulation, we demonstrate the ways in which plausibly valid instruments can mask important weak instrument biases. We conclude with a discussion of solutions that applied researchers can deploy when faced with these identification challenges.

\section{$3 \quad$ When strong instruments are invalid}

To pass a rigorous peer review, each growth study employing an instrumental variable offers theoretical and empirical reasons to believe that the instrument is not substantially correlated with the regression's error term. It is well known that this is difficult to establish. There can be a multiplicity of theoretical arguments for and against any given exclusion restruction, the true error term is unobserved in all applied settings, and empirical tests of overidentifiying restrictions have notoriously low power - among other reasons. What is not as well known is that collectively the literature establishes the invalidity of some instruments that growth econometricians now use widely, calling into question broad classes of their findings.

Suppose that growth is determined by

$$
g=\beta_{0}+\sum_{i=1}^{k} \beta_{i} x_{i}+\varepsilon
$$

where $g$ is growth, the $x_{i}$ are a set of $k$ potentially endogenous determinants of growth, the $\beta$ are parameters to be estimated and $\varepsilon$ is an error term. Suppose we have an instrumental variable $z$ such 
that $E[z \varepsilon]=0$ but $E\left[z x_{i}\right] \neq 0 \forall i$. We now try to estimate $k$ separate regressions

$$
g=\beta_{0}+\beta_{i} x_{i}+\varepsilon_{i}, i=1, \ldots, k
$$

in each case instrumenting for $x_{i}$ with $z$. But unless for every $i$ it is the case that $\beta_{j}=0$ (or much more implausibly $x_{i} \approx x_{j}$ ) for all $j \neq i$, we have $E\left[z \varepsilon_{i}\right] \neq 0 \forall i$, and the instrument $z$ is invalid in every regression (2). In other words, if existing research has shown that $z$ is a strong instrument for a variable $x_{j}$ not included in a regression of the form (2) and $\beta_{j} \neq 0$, then $z$ need not be a valid instrument for $x_{i}$. Any estimate $\widehat{\beta}_{i}$ will be biased to an unknown degree in an unknown direction, throwing into question the credibility of all results from the regressions (2). As Durlauf, Johnson, and Temple (2005, p. 635) point out, "Since growth theories are mutually compatible, the validity of an instrument requires a positive argument that it cannot be a direct growth determinant or correlated with an omitted growth determinant".

\subsection{Original sins}

A prominent example is the widespread use of "legal origins" in growth regressions, a practice that has become the subject of frequent grumbling at conference coffee breaks. A flotilla of recent cross-country growth regressions has employed an indicator of the origin of a country's legal system (British, French, Scandinavian, and so on) as an instrument in a variety of regression specificationseach one of which suggests that the instrument is invalid in all of the other specifications. These studies have passed the rigors of peer review at general-interest journals and top field journals.

Friedman, Johnson, Kaufmann and Zoido-Lobatón (2000) use legal origin as an instrument for five separate measures of the "the quality of economic institutions" (corruption, tax rates, overregulation, etc.) in regressions with the size of the unofficial economy as the dependent variablewhich could directly affect growth. Djankov, La Porta, López-de-Silanes, and Shleifer (2003) use legal origin as an instrument for "the degree of formalism of the legal procedure", which they argue causes a decline in the quality of the legal system (its honesty, impartiality, ability to enforce contracts, and so on) that could be a major determinant of growth. Lundberg and Squire (2003) use legal origin as an instrument for inflation, the inequality of land ownership, and several other variables that they argue directly affect growth. If any two of these studies are correct, growth is 
determined by a form of equation (1) that renders instrumentation in the IV regressions (2) invalid.

It does not stop there. Alfaro, Chanda, Kalemli-Özcan, and Sayek (2004) use legal origin as an instrument for private sector credit, bank credit, and stock market capitalization, which they argue condition the effect of Foreign Direct Investment on growth. Levine, Loayza and Beck (2000) similarly use legal origin to instrument for three separate proxies for financial intermediation, all of which they argue cause economic growth. Glaeser, La Porta, López-de-Silanes, and Shleifer (2004) use legal origin as an instrument for "executive constraints" and average years of schooling in the population, with the level of income per capita as the dependent variable. Beck, Demirgüç-Kunt and Levine (2005) use legal origin as an instrument for "the relative size of the small and medium enterprise sector", which could be associated with growth. There are other examples.

The findings of these studies suggest that 1) at least one of them specifies the second stage correctly, since they reject the null of zero coefficients in the second stage, but therefore 2) instrumentation can be valid in at most one of them, and at worst none.

\subsection{Size matters - through various channels}

We turn to another instrument in widespread use, and dwell on it at greater length because its problems are less broadly recognized. Several recent cross-country studies published in general-interest journals and top field journals rest their identification strategies on the correlation of population size with some endogenous variable. In each case, the authors give plausible reasons why population size is not only a strong instrument but uncorrelated with their regressions' error terms: the fact that growth regressions do not generally find population scale effects (Rose, 2006; Easterly, 2009).

When viewed collectively, however, these studies exhibit a problem that confutes their careful arguments in support of instrument validity: Given that none of these studies include the other studies' endogenous variables as regressors, if population size is a strong and valid instrument in even one of these studies, then it is invalid in all of the others. In other words, the conjecture in Deaton (2010) that measures of country size can affect growth through multiple channels has empirical support.

This pattern emerges in several recent and prominently published regressions. Some investigators use population size (among other geographic characteristics) as an instrument for trade as a 
determinant of the level of income per capita (Frankel and Romer, 1999; Frankel and Rose, 2002)4 or its growth (Spolaore and Wacziarg, 2005). Others regress growth not on the level of trade but on an indicator of the mix of goods exported, instrumented by population size (Hausmann, Hwang and Rodrik, 2007), without controlling for the level of trade. Still others use population size as an instrument to identify the effect of foreign aid on democracy (Djankov, Montalvo and ReynalQuerol, 2008), which many studies find to correlate with growth in some fashion. ${ }^{5}$ Another approach uses country size - measured by area and level of GDP, but strongly correlated with population - to instrument for receipts of foreign direct investment (FDI) as a determinant of growth (Borensztein, De Gregorio and Lee, 1998).

The exclusion restriction necessary for population size to be a valid instrument for each of these endogenous variables is falsified by each of the other studies. Regardless of any theoretical and empirical case for instrument validity made by each paper in the group, population size can only be a strictly valid instrument in one of them at best, and none of them at worst. The degree to which each estimate is thereby biased could be small or large, but should not be ignored.

\subsection{Strength in numbers, but not validity}

The problem extends further than this, however, in a way that is not generally recognized. Many studies resort to multiple instruments, responding to criticism by pointing out that allegations of invalidity or weakness only apply to some of the instruments. It is common to gloss over the problem that the most valid instruments in the basket could be the weakest, and that the strongest could be the least valid. ${ }^{6}$

Building on the above discussion of the population size instrument, it is possible for a study

\footnotetext{
${ }^{4}$ The Frankel and Romer (1999) instrument actually contains information beyond country size. While controlling for $\log$ population and area in the structural equations of tables 2 and 3, Frankel and Romer demonstrate that their instrument remains strong with a $F$ statistic over 10. However, upon more rigorous examination of the exclusion restrictions implicit in this instrument, Frankel and Rose (2002) conclude that among the six plausibly exogenous geographic determinants of trade flows used to construct their predicted trade instrument, log population is the only one that violates the implicit overidentifying restrictions used in constructing the instrument. See footnote 15 of Frankel and Rose (2002). This result supports our claims in this section about the non-excludability of size.

${ }^{5}$ For investigations of the effect of democracy on growth, see for example Barro (1996), Tavares and Wacziarg (2001), Giavazzi and Tabellini (2005), Rodrik and Wacziarg (2005), Persson and Tabellini (2006), Persson and Tabellini (2007), and Papaioannou and Siourounis (2008).

${ }^{6}$ Hahn, Ham, Moon (2009) develop a variant of the Hausman test for instrument exogeneity in the presence of multiple possibly weak instruments. While their approach has some appeal in the setting we explore below, the test has been shown to be unable to control the size of hypothesis tests on the second stage parameters (see Guggenberger, 2009). Moreover, implementing the pre-test requires strong assumptions to categorize instruments as strong or weak calling into question the general applicability of such a procedure. Nevertheless, their procedure could prove a valuable tool for growth research moving forward.
} 
whose identification strategy appears to rest on an array of instruments to rely in fact entirely on population size. Rajan and Subramanian (2008) execute cross-section regressions of growth on foreign aid receipts, with aid instrumented by a complicated instrument constructed from aidrecipient population size, aid-donor population size, colonial relationships, and language traits. ${ }^{7}$ Rajan and Subramanian write, "Our instrument ... contains information that is not just based on recipient size" (footnote 16). ${ }^{8}$ But the instrument contains, in fact, almost no information beyond the size of the recipient's population. In Rajan and Subramanian's data, for the period 19702000, the in-sample correlation of log population and the constructed instrument is -0.93 . In the periods 1980-2000 and 1990-2000, this correlation is -0.95. In effect, Rajan and Subramanian are instrumenting for aid with population alone. ${ }^{9}$

This problem deserves additional discussion, since it is common in applied work to rest identification on a group of instruments without making explicit which of them bears the burden of identification and therefore the key burden of validity. Frankel and Romer (1999) demonstrate that their geography-based instrument contains information beyond country size by including log population and $\log$ area as additional instruments in the second-stage. ${ }^{10}$ Taking this minimalist approach,

\footnotetext{
${ }^{7}$ Rajan and Subramanian construct their instrument in a "zero-stage" specification by regressing bilateral aid flows as a fraction of recipient GDP on recipient and donor characteristics. They use the resulting coefficients to calculate predicted bilateral aid flows. They sum these predicted bilateral flows across donors to arrive at predicted total aid receipts for each recipient country as a fraction of recipient GDP. This predicted total, a constructed instrument for true aid receipts, becomes the excluded instrument in a series of two-stage least squares regressions of economic growth on aid receipts and a set of control variables. The instrument is: $a_{d r} \equiv \frac{A_{d r}}{Y_{r}}=\sum_{i=0}^{7} \beta_{i} I_{i, d r}+$ $\sum_{i=0}^{5} \beta_{i+8}\left(\ln P_{d}-\ln P_{r}\right) I_{i, d r}+v_{d r}$, where $A_{d r}$ is dollars of aid given by donor $d$ to recipient $r, Y_{r}$ is the GDP of $r, \beta_{0}$ through $\beta_{13}$ are regression coefficients, $P_{d}$ is donor-country population, and $P_{r}$ is recipient-country population. The $I$ 's are a set of time-invariant country dummy variables describing the country dyad: a current or past colonial relationship $\left(I_{1}\right)$; a current or past colonial relationship with the United Kingdom $\left(I_{2}\right)$, France $\left(I_{3}\right)$, Spain $\left(I_{4}\right)$, or Portugal $\left(I_{5}\right)$; common language $\left(I_{6}\right)$; and a current colonial relationship $\left(I_{7}\right)$. Finally, $I_{0, d r}=1 \forall d, r$ and $v_{d r}$ is an error term. The estimated coefficient vector $\widehat{\beta}$ is then used to generate predicted bilateral flows $\bar{a}_{d r}$, which are summed across donors to create the constructed instrument $\bar{a}_{r}=\sum_{d} \bar{a}_{d r}$, which then instruments for aid receipts $a_{r} \equiv A_{r} / Y_{r}$ in the cross-section growth regression $g_{r}=\gamma_{1} a_{r}+X_{r}^{\prime} \Theta+u_{r}$, where $g_{r}$ is real GDP per capita growth, $X_{r}$ is a vector of country characteristics, $\gamma_{1}$ is a regression coeffcient, $\Theta$ is a vector of regression coefficients, and $u_{r}$ is an error term.

${ }^{8}$ They justify this claim (in their table 5 , panel C) by using one measure of country size (population) as an implicitly excluded instrument in the construction of $\bar{a}_{r}$ and, in a robustness check, showing that the constructed instrument $\bar{a}_{r}$ retains strength when a different measure of country size (land area) is included as an additional explicitly excluded instrument. But the only way to accurately assess whether or not $\bar{a}_{r}$ contains information beyond population size is to test whether or not it retains significance when population itself is included as a separate instrument as Frankel and Romer (1999) do (see footnote 4 above), and as we do below.

${ }^{9}$ Arndt, Jones, and Tarp (2009) utilize slightly adjusted versions of the Rajan and Subramanian (2008) instrument to estimate a battery of alternative program evaluation-inspired approaches to identifying the effect of foreign aid on growth. Their primary results, nonetheless, still rely on the validity of country size as an instrument for foreign aid. As the authors acknowledge "...we consider their [Rajan and Subramanian] instrument does capture variation in the allocation of aid that is plausibly exogenous to economic performance" (Arndt, Jones, and Tarp, 2009). This claim still misses the fundamental incompatibility of the Rajan and Subramanian identification strategy with other approaches in the growth literature.

${ }^{10}$ Although the Frankel and Romer (1999) approach did not go far enough to convince some skeptics (Rodríguez and Rodrik, 2001; Kraay, 2008), the validity of their instrument and robustness of their results have withstood more
} 
we explore in Tables 1 and 2 the role of population as an instrument using the original data of Rajan and Subramanian.

Table 1 shows that all instrumentation power comes from the population instrument. Column 1 exactly reproduces a representative cross-section regression (Rajan and Subramanian Table 4, column 2). Instrumentation is very strong, as indicated by the first-stage $F$ statistics - the Cragg and Donald (1993) F and Kleibergen and Paap (2006) rk Wald F statistic (hereafter Kleibergen-Paap $F$ statistic) - at the bottom of the table. ${ }^{11}$ Column 2 includes log population in the second stage, and instrument strength collapses. ${ }^{12}$ Column 3 discards Rajan and Subramanian's constructed instrument altogether and uses log population alone as an instrument for aid, giving results nearly identical to those in column 1 . Table 2 shows only the first-stage $F$ statistics from the other Rajan and Subramanian cross-section regressions: first in exact replication of their results, then with population deleted from the construction of their instrument, then with the instrument constructed based only on population and its interactions. In all cases, aid is weakly instrumented when information about population is absent from the constructed instrument, and strongly instrumented when only those variables containing information about population are present.

The Rajan and Subramanian cross-section method is indistinguishable from instrumenting exclusively with aid-recipient population. The subsequent discussion of the validity of any other variable in the instrument matrix, then, is not informative about the effect of aid on growth. What matters is the validity of the instrument that strongly identifies causation. Since that is only country size, the Rajan and Subramanian analysis faces the same problem faced by the other papers resting on the population instrument: All of the aforementioned papers that use the population instrument

demanding specifications and overidentifying restrictions Noguer and Siscart (2005).

${ }^{11}$ Because the authors use heteroskedasticity-robust standard errors in all regressions, use of the Kleibergen-Paap statistic is more appropriate; it generalizes the Cragg-Donald statistic to the case of non-i.i.d. errors, allowing for heteroskedasticity, autocorrelation and/or cluster robust statistics Baum, Schaffer and Stillman (2007). In the special case of a single endogenous regressor considered in this section, though, the Kleibergen-Paap and Cragg-Donald Wald statistics are respectively simply the standard robust and non-robust first-stage $F$ statistics.

${ }^{12}$ According to Stock and Yogo (2005), the Cragg-Donald $F$ statistic must exceed 5 if we are to be confident at the $5 \%$ level that the bias to the coefficient estimate on the aid variable is less than $30 \%$ of the OLS bias. Critical values have not been tabulated for the Kleibergen-Paap $r k$ statistic since the specific thresholds depend on the type of violation of the i.i.d. assumption, which invariably differ widely across applications. Nevertheless, standard firststage $F$ statistics well below unity are unlikely to exceed even the most generously low thresholds for unbiasedness. Additionally, we can rely on the Kleibergen-Paap Lagrange-Multiplier test of underidentification-a generalization of the Anderson canonical correlations test to non-i.i.d. errors for which one can utilize standard hypothesis testing procedures based on the $\chi^{2}\left(L-K_{1}+1\right)$ distributed statistic where $L$ is the number of excluded instruments and $K_{1}$ is the number of endogenous regressors. Under the null hypothesis, the equation is underidentified, which offers, in general, a much lower hurdle than the weak identification tests of Stock and Yogo (2005). With a p-value of 0.77, this test in column 2 fails to reject the null. 
invalidate its usage in these studies, since the regressions there do not control for the level of trade, the mix of goods exported, FDI, or democracy. And the Rajan and Subramanian exercise does not resolve important questions about the validity of the population instrument in all of the other papers that use it because those papers do not control for aid receipts in the second stage.

This problem extends beyond straightforward cross-section models to dynamic panel regressions as well. As an example, we consider the 10 year panel regressions in Hausmann, Hwang and Rodrik (2007). The authors utilize two estimators: a pooled 2SLS estimator with log population and $\log$ area as instruments, and the Blundell and Bond (1998) dynamic panel GMM estimator with instrumental variables that include log population and log area as well as the standard set of lagged covariates employed in this popular estimation strategy (see Section 3 for a detailed discussion of the estimator).

Using the original data of Hausmann, Hwang and Rodrik, Table 3 demonstrates how assumptions about the excludability of country size can drive identification of key parameters of interest even in a dynamic panel setting with numerous non-size-based instruments. Columns 1 and 2 replicate the results from Table 9, columns 6 and 8 respectively of Hausmann, Hwang and Rodrik. ${ }^{13}$ Column 3 removes $\log$ population and log area from the difference equation instrument matrix, which leaves instrument validity and inference largely unchanged. Column 4 removes log population and log area from the levels equation instrument matrix, while column 5 removes the size variables from the instrument matrices in both equations. Finally, column 6 relaxes the assumption that country size is excludable and the results are similar to the preceding columns which both dropped the size instruments from the levels equation.

Despite the wide array of plausibly valid internal instruments in lagged levels and differences, the key result depends solely upon the excludability of country size from the main equation in levels - an equation which closely corresponds to the overidentified linear, pooled 2SLS specification in column 1. Comparing the Hansen overidentification test ( $J$ test p-value) across the six specifications in this table, a supportive trend emerges. As we treat country size as non-excludable in progressively more equations in the system, our confidence in the collective validity of the instruments increases as in

\footnotetext{
${ }^{13}$ Despite utilizing their Stata code and original dataset, the system GMM replication in column 2 differs slightly albeit immaterially from the published results.
} 
the latter columns we are unable to refute the null of valid identifying restrictions (or correct model specification).

That country size strongly identifies only cross-sectional variation in trade composition frustrates our interpretation of any causal, time-varying relationship among the endogenous variables. The potential dynamic causal mechanism in this scenario is reduced to a pooled, static model as in Boone (1996) who was the first to use log population as an instrumental variable for foreign aid receipts in a 2SLS regression with investment growth as the outcome of interest. ${ }^{14}$ Hausmann, Hwang and Rodrik point out this precise problem in their pooled 2SLS regression, but do not indicate that the additional instruments employed in the GMM estimator may fail to solve the problem. ${ }^{15}$ Despite the large number of non-size-based instruments in the Blundell and Bond estimator, the short 10 year panel in Hausmann, Hwang and Rodrik, like their cross-sectional counterparts in Rajan and Subramanian, depends crucially on size-based instruments shown invalid in this setting by other studies.

We can go beyond mere suspicion that residuals in some of these studies are correlated with the endogenous variables in the other studies. Table 4 shows this within the Rajan and Subramanian framework. Here we perform a series of OLS regressions, each with a candidate growth determinant on the left-hand side that has been omitted from the Rajan and Subramanian regressions. The righthand side variables in each case are the second-stage regressors used by Rajan and Subramanian, plus log population. The table reports the point estimate and standard error for the coefficient on $\log$ population in each case. Log population has a statistically significant partial relationship with several variables that are plausible growth determinants. These include trade (Frankel and Romer, 1999), foreign direct investment (Borensztein, De Gregorio and Lee, 1998), education expenditure (Bosworth and Collins, 2003), inequality (Forbes, 2000), government consumption (found to correlate with country size by Alesina and Wacziarg (1998), and acknowledged as a robust growth determinant by Sala-i-Martin, Doppelhofer and Miller (2004)), alongside multiple others. ${ }^{16}$

\footnotetext{
${ }^{14}$ Much like Rajan and Subramanian, country size proved to be the sole source of identification in Boone (1996) where the main 2SLS (and cross-section) results. Boone's other instruments, political proxies for relationships with major donor countries, are extremely weak predictors of aid flows. Results available upon request.

15 "The variables used as instruments [log population and log area] fail the overidentification test in columns (2) and (6) [pooled 2SLS], most likely because they are persistent series akin to country fixed effects in a panel. Reassuringly, columns (4) and (8) show that the GMM setup where lagged levels and differences are used as instruments passes both the overidentification test and exhibits no second order correlation" (Hausmann, Hwang and Rodrik, 2007, footnote $9)$.

${ }^{16} \mathrm{~A}$ further complication arises when one considers relaxing the assumption of linearity in the endogenous variables
} 


\section{When valid instruments are weak}

So far we have discussed cases of strong instruments whose invalidity is difficult to detect. We turn now to cases of plausibly valid instruments whose weakness is difficult to detect.

The advent of GMM estimators in panel growth regressions has been a boon to growth empiricists. These estimators take advantage of a much larger array of exclusion restrictions than does two-stage least squares: The dynamic panel estimator of Arellano and Bond (1991) instruments for currentperiod differences in endogenous variables with a matrix of many lagged levels of predetermined right-hand side variables, and the related system estimator of Arellano and Bover (1995) and Blundell and Bond (1998) (hereinafter Blundell-Bond) additionally instruments for current-period levels with once- or twice-lagged differences. These estimators offer a battery of potentially valid instruments in most cross-country panels used in growth empirics. ${ }^{17}$

In particular, the general estimating equation is of the form

$$
g_{i, t}=\alpha y_{i, t-1}+\mathbf{x}_{i, t}^{\prime} \boldsymbol{\beta}+\psi_{i}+\nu_{i, t}
$$

where $y_{i, t-1}$ is $\log$ GDP per capita in country $i$ at time $t-1$ from the World Bank or Penn World Tables, $g_{i, t}$ is either percentage growth $\frac{y_{i, t}-y_{i, t-1}}{y_{i, t-1}}$ or $\log \left(y_{i, t}\right)$ and $\mathbf{x}_{i, t}$ is a vector of growth determinants at time $t$ (or $t-1$ ), $\psi_{i}$ is a country fixed effect or time-invariant heterogeneity, and $\nu_{i, t}$ is an idiosyncratic shock. Arellano-Bond "difference GMM" estimation transforms (3) into first-differences and exploits the moment conditions $E\left(y_{i, t-j} \Delta \nu_{i, t}\right)=0$ and $E\left(\mathbf{x}_{i, t-k} \Delta \nu_{i, t}\right)=0$ for $t=3, \ldots, T$, $j=2, \ldots T$ and $k=1, \ldots T$. While all researchers treat $y_{i, t-1}$ as endogenous, effectively instrumenting $\Delta y_{i, t-1}$ with $y_{i, t-j}$ or $y_{i, t-j-1}$, most have a particular interest in some possibly singleton subset of growth determinants in $\mathbf{x}$. The literature varies widely in whether one then (a) treats that specific subset as endogenous or predetermined - instrumenting with $\mathbf{x}_{i, t-k-1}$ and $\mathbf{x}_{i, t-k}$, respectively - and other elements of $\mathbf{x}$ as exogenous or (b) regards all elements of $\mathbf{x}$ as endogenous. This choice can

of interest. Suspend disbelief and assume that population size is a valid instrument for one and only one of the abovementioned studies, in Rajan and Subramanian, for example. Since this instrument has been shown to provide the sole source of identification even in 2SLS regressions with additional instruments, it is implausible and arguably impossible that one could identify endogenous nonlinearities, via specifications including endogenous quadratic, cubic, or interaction terms. We explore this situation further in Appendix A.

${ }^{17}$ Caselli, Esquivel and Lefort (1996) and Levine, Loayza and Beck (2000) were respectively the first to employ the Arellano-Bond and Blundell-Bond estimators in the empirical growth literature. Bond, Hoeffler and Temple (2001) characterize the appropriateness of these exclusion restrictions in the context of estimating the canonical Solow growth model, while Hauk and Wacziarg (2009) point out that, at least in theory, exogenous growth models do not necessarily prescribe the use of an instrumental variables framework. 
have important consequences for the strength of identification and hence the quality of inference. Another key choice concerns the number of lags, $j$ and $k$, used as instruments. Asymptotically, one would want to use the full set of lags, but as Roodman (2009b) establishes and as we reaffirm below, such choices often have nontrivial finite sample consequences.

Developed in response to the well-known weak instruments problem in difference GMM, the "system GMM" estimator augments the Arellano-Bond difference (DIF) equation with an equation in levels (LEV). Specifically, this now default estimator ${ }^{18}$ exploits an additional set of moment conditions $E\left(\Delta y_{i, t-1} \psi_{i}\right)=0$ and $E\left(\Delta \mathbf{x}_{i, t-1} \psi_{i}\right)=0$ for $t=3, \ldots, T$, instrumenting for the growth determinants in (3) in levels with their lagged differences. In theory, the myriad instruments offer a credible identification strategy for researchers aiming to test the canonical Solow growth model or to highlight a salient source of heterogeneity in growth rates across countries.

Often, however, a crucial question goes unexplored in applications of this new econometric technology: How much of the variance in the endogenous variables is explained by the instruments? A standard test for weak instruments in dynamic panel GMM regressions does not currently exist, so measuring instrument strength empirically is nontrivial. ${ }^{19}$ Until now, skeptical researchers have been mostly concerned with finite-sample biases stemming from weak instruments in the ArellanoBond estimator and violations of the exclusion restrictions in the Blundell-Bond estimator. ${ }^{20}$ What most have failed to address, however, is a potentially equally important problem, weak instruments in system GMM. Although generally thought to be more robust to weak instruments than difference GMM, recent work shows that the system estimator can also suffer from serious weak instrument biases (Bun and Windmeijer, 2010; Hayakawa, 2009). What's more, the weak instruments problem in system GMM could compound what might otherwise be slight departures from the requisite mo-

\footnotetext{
${ }^{18}$ Recent papers, e.g. Hausmann, Hwang and Rodrik (2007), do not consider the Arellano-Bond estimator at all, opting instead to present only results using the Blundell-Bond procedure.

${ }^{19}$ See Stock and Wright (2000) on why the weak instrument diagnostics for linear IV regression do not carry over to the more general setting of GMM. In a recent working paper, Kiviet (2008) propoes a framework for weak instrument tests in dynamic panel GMM. By establishing a novel correspondence between linear IV/2SLS and GMM estimation, Kiviet is able to map the familiar concentration parameter from IV/2SLS into a tractable GMM analogue. At the time of writing, however, the proposed closed form analytics and simulation results have only been presented for the Anderson and Hsiao (1982) estimator and not the more complicated Arellano-Bond or Blundell-Bond estimators used in the growth literature.

${ }^{20}$ Bobba and Coviello (2007), for example, demonstrate that the null result in Acemoğlu, Johnson, Robinson and Yared (2005) is reversed upon augmenting the weakly instrumented difference estimator with the levels equation in the system estimator. Roodman (2009b) demonstrates the sensitivity of the results of Levine, Loayza and Beck (2000) to the exclusion of lagged differences in the levels equation of the system estimator run on smaller instrument matrices. By necessity we discuss weak instruments in the DIF equation of the system estimator, but we explicitly leave the validity issue aside as its empirical importance has been addressed elsewhere (Roodman, 2009b; Hauk and Wacziarg, 2009).
} 
ment condition. In practice, most applications of system GMM simply assume that instruments are strong. We argue that instrument strength is an empirical question that can and should be directly tested in dynamic panel growth regressions.

Below we investigate instrument strength in a variety of applications of system GMM: first in simulated data, and then in several influential growth regressions recently published in top field and general-interest journals. We follow a simple approach to assessing instrument strength in dynamic panel GMM regressions advanced analytically by Bun and Windmeijer (2010) and Hayakawa (2009) and heuristically in various settings (Newey and Windmeijer, 2009; Blundell and Bond, 2000; Roodman, 2009a; Dollar and Kraay, 2003). Specifically, we construct the Holtz-Eakin, Newey and Rosen (1988) GMM instrument matrix used in the difference and levels equation of the system estimator, and carry out the corresponding regressions using two-stage least squares (2SLS). Such 2SLS analogues offer a simple and transparent test of instrument strength in a closely related setting.

The formal justification for this approach can be found in Hayakawa (2009) and Bun and Windmeijer (2010). Blundell, Bond and Windmeijer (2000) first demonstrated that the system estimator is an optimally weighted average of the difference and levels equations with the weights on the levels equation moments increasing in the weakness of the difference equation instruments. ${ }^{21}$ So, if instrumentation of contemporaneous differences by once, twice or multiply lagged levels is weak, and instrumentation of contemporaneous levels by lagged differences is weak, this casts great doubt on the ability of GMM estimators to yield strong identification as used in these settings. Formalizing this intuition, Bun and Windmeijer establish a set of tractable bias approximations demonstrating the explicit connection between cross-sectional concentration parameters and instrument strength in the panel 2SLS analogues that we estimate.

Extending the results in Bun and Windmeijer to the common case of multiple endogenous variables, we examine particularly whether the additional moment conditions used in system GMM are actually strong enough to compensate for the well-established weak instruments problem in difference GMM estimation of growth models. We appeal to the results of Blundell, Bond and Windmeijer

\footnotetext{
${ }^{21}$ The authors make this simple yet powerful point in the panel $\operatorname{AR}(1)$ model without covariates. The system estimator delivers the autoregressive point estimate of $\hat{\alpha}_{s}=\tilde{\delta} \hat{\alpha}_{d}+(1-\tilde{\delta}) \hat{\alpha}_{l}$ where $\hat{\alpha}_{l}$ is the autoregressive point estimate from the LEV equation, $\hat{\alpha}_{d}$ is the autoregressive point estimate from the DIF equation, and $\tilde{\delta}=\frac{\hat{\pi}_{d}^{\prime} \mathbf{Z}_{d}^{\prime} \mathbf{Z}_{d} \hat{\pi}_{d}}{\hat{\pi}_{d}^{\prime} \mathbf{Z}_{d}^{\prime} \mathbf{Z}_{d} \hat{\pi}_{d}+\hat{\pi}_{l}^{\prime} \mathbf{Z}_{l}^{\prime} \mathbf{Z}_{l} \hat{\pi}_{l}}$, where $\hat{\pi}_{j}$ are the first-stage estimates using the instruments $\mathbf{Z}_{j}$ for $j=l, d$ in the LEV and DIF equation respectively. This familiar setup motivates our heuristic use of the 2SLS analogues.
} 
(2000) and Stock and Yogo (2005) in justifying our extension of the AR(1) analytics to the case of multiple endogenous regressors. In particular, we do not examine the strength of identification in the individual "first-stage" GMM regressions in isolation, but rather, we rely on the Cragg-Donald and Kleibergen-Paap matrix versions of the Wald statistic to test whether the instruments jointly explain enough variation in the multiple endogenous regressors to conduct meaningful hypothesis tests of causal effects. In models with more than one endogenous variable, Stock and Yogo propose using as a measure of instrument strength the smallest eigenvalue of the matrix analogue of the first-stage $F$ statistic. A major drawback to the Stock and Yogo approach is its reliance on an assumption of homoskedastic errors. As noted above, however, Kleibergen and Paap (2006) develop the $r k$ statistic which relaxes this assumption at the cost of less clarity in interpreting the magnitude of the test statistic. We report both statistics throughout the analysis below and rely on the Stock and Yogo discussion of critical values for weak instrument diagnostics.

Despite the large number of instruments in several specifications considered below, the Stock and Yogo approach to testing weak instruments still presents itself as a powerful diagnostic tool for our 2SLS analogues of dynamic panel GMM regressions. In fact, Hall, Inoue, and Shin (2008) develop a tractable method for using the Stock and Yogo diagnostics to select optimal instruments in GMM regressions via examination of 2SLS analogues. Their results show that a Stock and Yogo pre-test can actually be more powerful than using weak-instrument robust inference procedures with the full set of (possibly suboptimal) instruments. Moreover, Stock and Yogo provide critical values for test statistics calculated from regressions with up to 100 instruments. Not only do those critical values exhibit an obvious slow rate of decay as instruments increase beyond 30 or 40, but numerical results suggest their procedure is consistent for any number of instruments (p. 90).

\subsection{Monte Carlo results}

Our first step is to show that the system GMM estimator can often have poor size and power properties, depending crucially on the extent of endogeneity and on the strength of instrumentation. This is a different focus than the simulations in Blundell, Bond and Windmeijer (2000), Hauk and Wacziarg (2009), and Bun and Windmeijer (2010), though we follow their specification, which differs slightly from (3). We simulate: 


$$
\begin{aligned}
& y_{i, t}=\beta y_{i, t-1}+\gamma d_{i, t}+\psi_{i}+\nu_{i, t} \\
& d_{i, t}=\zeta d_{i, t-1}+\theta_{i}+\phi_{i, t}
\end{aligned}
$$

where the initial conditions $y_{i, 1}=\left(\psi_{i}+\left(\gamma \theta_{i} /(1-\zeta)\right) /(1-\beta)+\nu_{i, 1}\right.$ and $d_{i, 1}=\left(\theta_{i}\right) /(1-\zeta)+\phi_{i, 1}$ are sufficient to impose mean stationarity. The errors are distributed as

$$
\nu_{i, t}, \phi_{i, t} \sim N\left(\left(\begin{array}{c}
0 \\
0
\end{array}\right),\left(\begin{array}{cc}
\sigma^{2} & \omega \\
\omega & \sigma^{2}
\end{array}\right)\right) \quad \text { and } \quad \psi_{i}, \theta_{i} \sim N\left(\left(\begin{array}{l}
0 \\
0
\end{array}\right),\left(\begin{array}{ll}
1 & 0 \\
0 & 1
\end{array}\right)\right)
$$

Note that the correlation coefficient for the shocks is $\rho=\frac{\omega}{\sigma^{2}}$.

Figure 1 shows results from this simulation with $\gamma=0.3$ and $\beta=0.2$, in 500 repetitions. We choose $\gamma=0.3$ as plausible estimates of many growth determinants in the literature are indeed quite small. The horizontal axis shows different assumed values of $\zeta \in[0,1)$, indicating the persistence of $d$ over time, and the vertical axis compares the estimated $\hat{\gamma}$ (solid black line) to the true $\gamma$ (dotted red line). The dashed lines show the average 95\% confidence interval on $\hat{\gamma}$ across all repetitions. The top part of the figure shows the results for the difference GMM estimator, the bottom part for the system GMM estimator. ${ }^{22}$ Each small panel of the figure shows a different combination of the extent of endogeneity $\rho \in\{-0.1,-0.5,-0.9\}$, and the shock variance $\sigma^{2} \in\{1,10,100\}$ as suggested in Bun and Windmeijer (2010). For given variances of the fixed effects, $\psi_{i}$ and $\theta_{i}$, the variation in $\sigma^{2}$ provides one means of affecting instrument strength.

The performance of the difference GMM estimator is poor. In no case does the estimate of $\hat{\gamma}$ both reject the hypothesis $\gamma=0$ and fail to reject the hypothesis that $\gamma=0.3$. For the more negative values of $\rho$, bias is so extensive that the true value of $\gamma$ is often rejected. The downwardly biased difference GMM estimates are consistent with the Monte Carlo findings elsewhere (Blundell and Bond, 1998) although our results seem to imply biases even at quite low levels of persistence in $d$ and $y$. The system GMM estimator performs better: The estimate of $\hat{\gamma}$ only rejects the true value when $\zeta$ is low, that is when $d$ is not sufficiently persistent over time. It is able to reject the hypothesis $\gamma=0$, but only for very high levels of $\zeta$, which is consistent with the original motivation for the system estimator in Blundell and Bond. In sum, the estimates yielded can differ sharply

\footnotetext{
${ }^{22}$ All results use two-step corrections, cluster on groups $i$, include time dummies in all equations, treat $y_{i, t-1}$ and $d_{i, t}$ as endogenous, and include the full unrestricted set of lags in the difference equation instrument matrix.
} 
from the true coefficient when there is a high degree of endogeneity, when $d$ is not persistent over time, and when the shock variance $\sigma^{2}$ is low.

Figure 2 suggests that these problems are related to weak identification. Here the vertical axis shows the Kleibergen-Paap $F$ statistic in a 2SLS regression analogous to each regression in Figure 1. In the upper part of Figure 2, current differences are instrumented by the same Holtz-Eakin, Newey and Rosen GMM instrument matrix of lagged levels used in the difference GMM estimates of Figure $1 .^{23}$ In the lower part of Figure 2, current levels are instrumented by the same matrix of lagged differences used in the levels equation of the system GMM estimates in Figure 1. Kleibergen-Paap statistics lower than roughly 4 raise doubts about the strength of instrumentation.

A clear pattern emerges: When instrumentation is weak in the 2SLS analogues of Figure 2, the performance of difference and system GMM estimates of $\gamma$ are poor in Figure 1. When endogeneity is limited (e.g. when $\rho=-0.1$ ) or when instrumentation in the 2SLS analog is strong (e.g. when $\zeta=0.8$ and $\left.\sigma^{2}=100\right)$, the estimates $\hat{\gamma}$ show excellent size and power properties. Figures 3 and 4 repeat the same exercise with $\beta=0.8$, so that $y$ is more persistent over time, with essentially the same result. The one slight difference is that instrumentation is weaker at higher levels of $\sigma^{2}$ in this case.

Figures 1-4 are sobering: Under reasonable parameter assumptions, the system GMM estimator is quite capable of leading a researcher to spurious conclusions - that $d$ does not cause growth when it does, or that $d$ has a negative effect on growth when the true effect is positive. A major part of the problem appears to be that in many cases there is no good reason to believe that lagged levels of the regressors explain a large portion of the variance in current differences, or vice versa. In these simulation results this is transparent by construction. We now proceed to illustrate that this concern may be far from hypothetical and may apply to real published research. In the following subsections, we deploy the above method to test instrument strength in several recently published growth regressions based on system GMM.

\footnotetext{
${ }^{23}$ The Holtz-Eakin, Newey and Rosen difference equation instrument matrix contains a separate column for each period and lag depth with the other column elements containing zeros. The corresponding levels equation instrument matrix contains the once lagged difference for each period. See Roodman (2009a) for a detailed discussion.
} 


\subsection{Financial intermediation: Abundant instruments versus strong in- struments}

Table 5 revisits the panel GMM results of Levine, Loayza and Beck (2000) using the original data. ${ }^{24}$ Column 1 reproduces a representative regression of growth on "liquid liabilities" (their Table 5, column 1). Column 2 gives the results of the closest reproduction of this regression we could achieve using the authors' dataset, and the results match relatively well. ${ }^{25}$ Column 3 carries out the same regression using simple pooled OLS. In columns 4 and 5, we purge the country fixed effects from the regression by first-differencing (FD) and within-transformation (FE), the OLS analogues to the difference and levels equations. Theoretical evidence on dynamic panel bias (Nickell, 1981) suggests that pooled OLS and fixed effects OLS should produce respectively the upper and lower bounds for a consistent point estimate on the lagged dependent variable. Bond (2002) shows why consistent system or difference GMM estimates will lie squarely within these theoretical bounds.

The fact that the point estimate on lagged GDP per capita in the replicated regression of column 2 lies slightly above the pooled OLS estimate in column 3 suggests that the system estimator may be producing upwardly biased results (though this is not the case in the published regressions). While weak instruments typically bias difference estimates downward, Bun and Windmeijer (2010) demonstrate how system estimates can be biased upward with the biases increasing in the ratio of the variance of the time-invariant heterogeneity to the idiosyncratic shocks. Recall that our simulation results in the preceding section similarly present the least biases for high values of $\sigma^{2}$, or low values of this ratio. In column 5, that ratio of variances is nearly 25 , which is many orders of magnitude larger than the one-to-one ratio upon which Blundell and Bond (1998) predicated the system estimator's consistency. Column 6 regresses differenced growth on differenced regressors, instrumented by lagged regressor levels analogous to the difference estimator. Both the Cragg-Donald and Kleibergen-Paap Wald-type statistics and the lower-hurdle Kleibergen-Paap LM test of underidentification show that

\footnotetext{
${ }^{24}$ This paper conducts similar regressions with three different endogenous measures of financial intermediation: "liquid liabilities" (currency plus demand and interest-bearing liabilities of banks and non-bank financial intermediaries) as a fraction of GDP; "commercial-central bank" (assets of deposit money banks divided by assets of deposit money banks plus central bank assets); and "private credit" (credit by deposit money banks and other financial institutions to the private sector as a fraction of GDP). Here we analyze the results for liquid liabilities alone, but we conducted the same analysis for all three variables with substantively identical conclusions.

${ }^{25}$ This replication is due to Roodman (2009b). It remains unclear why replications of the Levine, Loayza and Beck (2000) regressions do not match more closely, especially considering that all replications employ the original data provided by the authors (see Appendix B). Some, but not all, of the discrepancy could be due to differences in the estimator as deployed in the original Gauss program DPD98 used by the authors relative to the xtabond2 program for Stata, which we utilize here.
} 
instrumentation is very weak, far too weak for instrumentation to remove a substantial portion of OLS bias.

An additional problem lurks below the surface: The sample contains 77 countries, and 75 different instrumental variables are used in the system estimator. ${ }^{26}$ The large number of instruments may actually result in a failure to expunge the endogenous components of the right-hand side variables, thereby biasing the coefficient estimates towards those from the OLS estimator (Roodman, 2009b). In the limiting case, a 2SLS regression that had one instrument for each observation would show strong instrumentation but would produce coefficients exactly equal to those produced by OLS, and would not address endogeneity bias at all. The problem is perhaps even more serious in panels in which the cross-sectional variation dominates the within variation as is common in growth regressions. Until recently the literature has offered little guidance on the appropriate number of instruments relative to the number of groups and time periods.

Roodman (2009b) introduces a practical method for addressing this problem of "too many instruments" in dynamic panel GMM estimation. He suggests first restricting the number of lagged levels used in the instrument matrix for the difference equation, ${ }^{27}$ but since Levine, Loayza and Beck (2000) restrict their original matrix to a single lag, we must try an alternative approach. By "collapsing" the instrument matrix, we can effectively combine the instruments into smaller sets while retaining the same information from the original 75 column instrument matrix. The "collapsed" matrix contains one instrument for each lag of the instrumenting variable instead of one instrument for each period and lag of the instrumenting variables. Roodman suggests that a liberal rule of thumb for identifying potential cases of "too many instruments" is to become concerned when the number of instruments is close to the number of groups, as in the present case. Column 7 shows the results with the instrument matrix collapsed; instrumentation predictably becomes even weaker. Instrumentation this weak - no matter how valid - is incapable of testing hypotheses about coefficients in the main regression.

To test for weak instruments in the system estimator, we must also examine the levels equation independently of but in the same manner as the difference equation treated in preceding columns.

\footnotetext{
${ }^{26}$ In both the levels and difference equations, 35 lagged regressors are used as instrumental variables, as well as the 5 period dummies included in the main equation.

${ }^{27}$ As conventionally applied in the empirical literature, the instrument matrix for the levels equation in the system estimator contains only one lagged difference for each endogenous variable in levels as additional moments would be redundant Arellano and Bover (1995).
} 
Columns 8 and 9 conduct this parallel exercise for the levels equation. Since the difference equation is so weakly instrumented, the burden of strong identification in the system estimator relies on the levels equation moments. In column 8 , the level of growth is regressed on the level of the regressors in a two-stage least squares framework, instrumented by the same lagged differences as in the levels equation of the system GMM estimator. Once again, instrumentation is far too weak to address any substantial portion of OLS bias, and when the instrument matrix is collapsed in column 9 the problem only worsens.

\subsection{Weak aid or weak instruments?}

Table 6 repeats this analysis for an entirely different set of regressions. It revisits the dynamic panel results of Rajan and Subramanian (2008) using the original data. Columns 1 and 2 exactly replicate their main Arellano-Bond (Table 9, column 1) and Blundell-Bond (Table 10, column 1) results. ${ }^{28}$ Column 3 shows the simple pooled OLS result, which appears remarkably similar to the system estimate in the preceding column. Columns 4 and 5 purge country fixed effects from the regression in column 3 via first-differencing (FD) and within-transformation (FE), bringing the results close to those in the difference GMM estimator in column 1. This per se is suggestive evidence that instrumentation in these panel regressions is too weak to improve on OLS. While the difference GMM point estimate on lagged GDP per capita lies below the fixed effects estimate, the system estimate in column 2 places the coefficient just within the range of plausibly consistent estimation. However, this suggestive evidence still neglects potential problems with weak instruments, which could manifest differently than traditional dynamic panel biases. Given that the ratio of the variance of the time-invariant individual effects to the variance of idiosyncratic errors is above 9 in column 5 , it is unlikely that the heuristic bounding exercise of Bond, Hoeffler and Temple (2001) can capture the range of necessary conditions for consistent estimation within the system GMM framework.

Thus, following the approach above, in column 6 we estimate the difference component of the

\footnotetext{
${ }^{28}$ Rajan and Subramanian include the second through seventh lags as instruments in both specifications. They note that they are employing up to eight lags, but given that their panel consists of eight periods and only the four five year periods since 1985 are actually used due to missing data on their institutional quality measure, their difference and system GMM specifications naturally do not include eighth lagged levels as instruments for any of the endogenous regressors. Also, although they claim to include an additional set of time-invariant, excluded instruments in their main difference-equation specifications (geography, ethnic fractionalization, Sub-Saharan Africa and East Africa) a Stata coding error results in their being dropped from the "first- stage" equations regressing differenced endogenous variables on lagged levels. To be consistent with their published results, we exclude these four time-invariant dummies from the Arellano-Bond regression in column 1 and the difference equation in the Blundell-Bond regression in column 2 , as well as the 2SLS analogues in subsequent columns. Including them results in an immaterial improvement in the weak identification statistics (results available upon request).
} 
system estimator in a 2SLS regression with exactly the same sequential moment conditions. The Cragg-Donald $F$ statistic falls well below unity, suggesting substantial finite sample biases, and although the Kleibergen-Paap statistic appears high, the perceived strength turns out to be a statistical artifact of including up to seven lags. If on the other hand, one simply collapsed the 120 column instrument matrix with up to seven lags, the $F$ statistics fall even lower in column $7 .{ }^{29}$ The relatively higher Kleibergen-Paap $r k$ statistic of 3.8 suggests that the standard Cragg-Donald test statistic might be sensitive to heteroskedasticity. But since we still cannot reject the null of underidentification based on the Kleibergen-Paap LM test, identification is still too weak to conduct meaningful hypothesis tests based on the difference equation alone. Columns 8 and 9 repeat the same exercise for the levels equation component of the system estimator. Column 8 demonstrates weak instruments in the standard wide instrument matrix, and collapsing exacerbates the problem still further. These results suggest that the similarity between the biased OLS estimates in columns 3-5 and the dynamic panel GMM estimates in columns 1 and 2 is not a coincidence.

\subsection{Beyond aid and credit}

The findings above are not peculiar to the specifications used in these two studies. In cross-country dynamic panel growth regressions with multiple endogenous covariates, it is unlikely that one can solve the weak instruments problem in the Arellano-Bond estimator by straightforward recourse to the richer system estimator of Blundell-Bond. With a weakly instrumented levels equation, the system estimates can exhibit biases of similar orders of magnitude to uncorrected OLS variants. While the estimation of growth models in a dynamic panel framework is intrinsically appealing, researchers applying these popular GMM estimators should be wary of interpreting not only significant but also null results.

In this section, we further examine the weak instruments problem in other recently published empirical applications. The goal is to highlight features of the data and panel setup that give rise to varying identification outcomes. Table 7 reports weak instruments diagnostics for the main system

\footnotetext{
${ }^{29}$ One could also solely or additionally reduce the size of the instrument matrix by simply restricting the number of lags as in Levine, Loayza and Beck (2000). Restricting the number of lags to one or two produces Kleibergen-Paap $r k$ statistics below unity, and we strongly fail to reject underidentification. These results are available upon request. Although Rajan and Subramanian note that restricting the lag depth in the GMM estimation of columns 1 and 2 does not affect their null results, these simple test statistics constructed from analogous 2SLS procedures point to more fundamental specification problems.
} 
GMM specifications in four studies published within the last five years. ${ }^{30}$ As before, we emphasize not the particular findings of each study but rather the sources and quality of identification of the key parameters of interest. For each of the studies, we report the relevant weak instrument test statistics for the 2SLS analogues of the difference (DIF) and levels (LEV) equations separately with the full and collapsed instrument matrices. ${ }^{31}$ The first panel of the table unpacks the Blundell-Bond estimates of the Solow growth equations on actual data in Table 13 of Hauk and Wacziarg (2009). Their implementation of the canonical augmented Solow model treats all RHS variables-physical capital, human capital, population and lagged income - as endogenous and instruments with the full set of available lags in the DIF equation. The resulting Cragg-Donald and Kleibergen-Paap statistics are all slightly below the conjectured Stock and Yogo (2005) thresholds. ${ }^{32}$ Nevertheless, these diagnostics suggest that the large DIF instrument set still explains some of the variation in the four endogenous variables.

Next, we return to the Hausmann, Hwang and Rodrik (2007) results examining their longer panel employing a five year periodization. The longer panel affords the authors a richer degree of within-country variation through which the internal GMM instruments derive predictive power for the three endogenous variables discussed in Section 2. The DIF and LEV equations both appear to have relatively strong instruments, but the results are less convincing when one collapses the instrument matrix. The size instruments, which proved to be the sole source of identification in the short panel, play much less of a role in the longer panel (results available upon request).

The third paper we consider is due to Voitchovsky (2005) who analyzes the heterogeneous impact of inequality on economic growth using an unbalanced panel of OECD countries from 1970-1995. Relying on household data from the Luxembourg Income Study (LIS), this study is bound to a particularly small sample of countries and years. We report our diagnostics for the baseline specification in Column 4, Table 2 (Voitchovsky, 2005, p. 287), in which five RHS variables are treated as endogenous - lagged income per capita, contemporaneous investment, lagged schooling, lagged

\footnotetext{
${ }^{30}$ Rank deficiencies resulted in irresolvable computational challenges to computing some of the test statistics, and hence a few cells of the Kleibergen-Paap and Cragg-Donald columns are left blank. The non-missing statistic in these rows should still be informative.

${ }^{31}$ Our replications of Hauk and Wacziarg (2009), Hausmann, Hwang and Rodrik (2007) and Dejong and Ripoll (2006) are exact. However, our replication of Voitchovsky (2005) is trivially different than the results published by the author; this is likely due to the fact that the author used Gauss, while we utilized Stata. The full set of results are available upon request.

${ }^{32}$ Stock and Yogo (2005) only tabulate results for up to three endogenous variables, but one should be able to extrapolate these critical values to "nearby" cases.
} 
gini coefficient, and lagged ratio of the $90 / 75$ th percentile of the income distribution. ${ }^{33}$ The author constructs a non-standard set of instruments, motivated by careful arguments against using the standard Blundell-Bond instrument matrix. For the DIF equation, the instruments include twice and thrice lagged income per capita, lagged investment, twice lagged and differenced schooling, and twice lagged and differenced inequality measures. For the LEV equation, the instruments include once lagged differenced investment and once and lagged differenced schooling; the inequality measures and lagged income per capita are treated as exogenous in the levels equation. The test statistics suggest the DIF equation is weakly instrumented while the LEV equation instruments fare better. However, since the two inequality measures, the key endogenous variables of interest, are treated as exogenous in the LEV equation, it is not clear how to interpret the estimated parameters on these two variables. The DIF equation instruments are likely too weak to identify the parameters, while the LEV equation further frustrates identification by allowing inequality to enter the system exogenously.

Lastly, we examine the system GMM estimates from Dejong and Ripoll (2006), a study arguing that the relationship between trade openness and economic growth differs across the ex ante distribution of income levels. We consider the authors' baseline estimates from the fourth column of Table 2 (p. 631). The regressions examine eight endogenous growth determinants: life expectancy, female schooling, male schooling, lagged income per capita, ad valorem tariffs (import duties as share of imports), tariffs $\times$ initial income/capita, investment/GDP, and government spending/GDP. The first four growth determinants are instrumented with once lagged levels, and the latter four are instrumented with twice lagged levels. Except the inexplicably high Kleibergen-Paap statistic for the un-collapsed DIF equation, the diagnostics point to serious weak instruments problems.

Collectively, the simulation results and six papers considered above sound a warning note about the credibility of unexamined growth empirics using difference and system GMM estimation. Where Hauk and Wacziarg attribute the evident biases in Blundell-Bond estimation to violations in the mean stationarity assumption, we find that weak instruments can also create serious problems. Unlike the initial conditions assumption, however, weak instruments can be diagnosed and (partially) addressed in many settings.

\footnotetext{
${ }^{33}$ Our results are qualitatively similar using the three preceding specifications in Table 2.
} 


\section{Lessons}

We demonstrate that invalid and weak instruments continue to be commonly used in the growth literature. This suggests that the warnings of Durlauf, Johnson, and Temple (2005) and others on this subject have gone unheard. Weak and/or invalid instruments do not assist researchers in conducting meaningful hypothesis tests about the causes of growth.

Most of the papers discussed here contain explicit policy implications based on their results. Without strong and valid identification of causal effects, however, policy implications are limited. Nevertheless, these studies remain valuable contributions to the literature for other reasonsespecially their innovations in method.

Economists will and should pursue pressing research questions on growth while methods remain imperfect. But we suggest a handful of guidelines for the next generation of growth empirics:

1. Generalize the theoretical underpinnings of an instrument to account for other published results with the same instrument. When an instrument has been used elsewhere in the literature, new users of that instrument bear the burden of showing that other important findings using that instrument do not invalidate its use in the new case. This can be done using a somewhat more generalized model that comprises causal pathways explored elsewhere with that instrument. Accounting for all plausible pathways through a "unified growth theory" is too high a standard, but accounting for the most prominent published pathways should be a minimum standard.

2. Deploy the latest tools for probing validity. Perfect instruments for growth determinants will remain elusive, but many underutilized tools exist to shine brighter light on the instruments we have. Imbens (2003) lays out a transparent method of assessing the sensitivity of a growth effect estimate to a given degree of correlation between instrument and error. Kraay (2008) and Conley, Hansen and Rossi (2008) explore how to conduct second-stage inference accounting for prior uncertainty about the excludability of the instrument. Ashley (2009) shows how the discrepancy between OLS and IV estimates can be used to estimate the degree of bias under any given assumption about the degree to which the exclusion restrictions are violated.

3. Open the black box of GMM. It is no longer sufficient to assert that the mere use of system GMM adequately addresses the risk of weak instrumentation in dynamic panel models. As applied 
econometricians wait for an analog of the Stock and Yogo (2005) weak instrument diagnostics suitable for dynamic panel GMM estimation, its use must be complemented by supportive evidence that the instruments explain a sufficient degree of the variance of the endogenous regressors (and not simply because so many instruments are used). Papers exploring growth determinants should explore the strength of candidate instruments in analogous two-stage least squares regressions, should explore robustness to Roodman (2009b) "collapsing" of the instrument matrix, should utilize optimal instrument selection procedures tailored to dynamic panel GMM Okui (2009), and should explore methods robust to weak instruments (Stock and Wright, 2000; Kleibergen, 2005, 2007; Kleibergen and Mavroeidis, 2009). ${ }^{34}$

\footnotetext{
${ }^{34}$ While this literature does not directly address the specific dynamic panel estimators employed in the growth literature, their methods can be applied with some effort. For a discussion on the application of some of these approaches, see Baum, Schaffer and Stillman (2007).
} 


\section{References}

Acemoğlu, Daron (2010), "Theory, General Equilibrium, Political Economy and Empirics in Development Economics," mimeo.

Daron, Simon Johnson, and James A. Robinson (2001), "The Colonial Origins of Comparative: An Empirical Investigation," 91 (5): 1370-1400.

Acemoğlu, Daron, Simon Johnson, James A. Robinson, and Pierre Yared (2005), "From education to democracy?" American Economic Review Papers and Proceedings 95: 44-49.

Albouy, David Y. (2008), "The colonial origins of comparative development: An investigation of the settler mortality data," NBER Working Paper 14130 (Cambridge, MA: National Bureau of Economic Research).

Alesina, Alberto and Romain Wacziarg (1998), "Openness, country size, and government," Journal of Public Economics 69 (1): 305-321.

Alfaro, Laura, Areendam Chanda, Şebnem Kalemli-Özcan, and Selin Sayek (2004), "FDI and economic growth: the role of local financial markets," Journal of International Economics 64 (1): $89-112$.

Anderson, T.W., and Cheng Hsiao (1982), "Formulation and Estimation of Dynamic Models Using Panel Data," Journal of Econometrics, 18 (1): 47-82.

Angeles, Luis and Kyriakos C. Neanidis (2009), "Aid effectiveness: The role of the local elite," Journal of Development Economics 90 (1): 120-134.

Arellano, Manuel, and Stephen Bond (1991), "Some tests of specification for panel data: Monte Carlo evidence and an application to employment equations," Review of Economic Studies 58(2): 277-297.

Arellano, Manuel and Olympia Bover (1995), "Another Look at the Instrumental Variable Estimation of Error-Components Models," Journal of Econometrics 68 (1): 29-52.

Arndt, Channing, Sam Jones and Finn Tarp (2009), "Aid and Growth: Have We Come Full Circle?" mimeo.

Ashley, Richard (2009), "Assessing the credibility of instrumental variables inference with imperfect instruments via sensitivity analysis," Journal of Applied Econometrics 24 (2): 325-337.

Barro, Robert J. (1991), "Economic Growth in a Cross Section of Countries," Quarterly Journal of Economics 106 (2): 407-443.

Barro, Robert J. (1996), "Democracy and Growth," Journal of Economic Growth 1 (1): 1-27.

Baum, Christopher F., Mark E. Schaffer, and Stephen Stillman (2007), "Enhanced routines for instrumental variables/GMM estimation and testing," Stata Journal 7 (4): 465-506.

Baumol, William J. (1986), "Productivity Growth, Convergence, and Welfare: What the Long-run Data Show," American Economic Review 76 (5): 1072-1085.

Beck, Thorsten, Aslı Demirgüç-Kunt, and Ross Levine (2005), "SMEs, growth, and poverty: Crosscountry evidence," Journal of Economic Growth 10 (3): 199-229.

Blundell, Richard and Stephen Bond (1998), "Initial Conditions and Moment Restrictions in Dynamic Panel Data Models," Journal of Econometrics 87 (1): 115-143. 
Blundell, Richard and Stephen Bond (2000), "GMM Estimation with Persistent Panel Data: An Application to Production Functions," Econometric Reviews 19 (3): 321-340.

Blundell, Richard W, Stephen R. Bond and Frank Windmeijer (2000), "Estimation in Dynamic Panel Data Models: Improving on the Performance of the Standard GMM Estimator" in B. Baltagi (ed.) Advances in Econometrics, Volume 15: Nonstationary Panels, Panel Cointegration, and Dynamic Panels, (JAI Elsevier Science).

Bobba, Matteo and Decio Coviello (2007), "Weak instruments and weak identification in estimating the effects of education on democracy," Economics Letters 96 (2): 301-306.

Bond, Stephen R. (2002), "Dynamic panel data models: a guide to micro data methods and practice," Portuguese Economic Journal 1 (2): 141-162.

Bond, Stephen R., Anke Hoeffler and Jonathan Temple (2001), "GMM Estimation of Empirical Growth Models," CEPR Discussion Paper No. 3048.

Boone, Peter (1996), "Politics and the effectiveness of foreign aid," European Economic Review 40 (2): 289-329.

Borensztein, Eduardo, Jose De Gregorio, and Jong-Wha Lee (1998), "How does foreign direct investment affect economic growth?" Journal of International Economics 45 (1): 115-135.

Bosworth, Barry P. and Susan M. Collins (2003), "The empirics of growth: An update," Brookings Papers on Economic Activity 2: 113-206.

Brock, William A. and Steven N. Durlauf (2001), "Growth empirics and reality," World Bank Economic Review 15 (2): 229-272.

Bun, Maurice J. G. and Frank Windmeijer (2010), "The Weak Instrument Problem of the System GMM Estimator in Dynamic Panel Data Models," Econometrics Journal 13 (1): 95-126.

Bun, Maurice and J.F. Kiviet (2006), "The Effects of Dynamic Feedbacks on LA and MM Estimator Accuracy in Panel Data Models," Journal of Econometrics 132 (2): 409-444.

Burnside, Craig, and David Dollar (2000), "Aid, Policies, and Growth," American Economic Review 90 (4): 847-868.

Caselli, Francesco, Gerardo Esquivel, and Fernando Lefort, (1996), "Reopening the Convergence Debate: A New Look at Cross Country Growth Empirics," Journal of Economic Growth 1 (3): 363-389.

Conley, Timothy G., Christian B. Hansen, and Peter E. Rossi (2008), "Plausibly exogenous," Working Paper, Booth School of Business (Chicago: University of Chicago).

Cragg, John G. and Stephen G. Donald (1993), "Testing identifiability and specification in instrumental variable models," Econometric Theory 9 (2): 222-240.

Dalgaard, Carl-Johan, Henrik Hansen, and Finn Tarp (2004), "On the empirics of foreign aid and growth," Economic Journal 114 (496): 191-216.

Deaton, Angus S. (2010), "Instruments, Randomization, and Learning about Development," Journal of Economic Literature 48 (2): 424-455.

DeJong, David N. and Marla Ripoll (2006), "Tariffs and Growth: An Empirical Exploration of Contingent Relationships," 88 (4): 625-640. 
Djankov, Simeon, Rafael la Porta, Florencio López-de-Silanes, and Andrei Shleifer (2003), "Courts," Quarterly Journal of Economics 118 (2): 453-517.

Djankov, Simeon, Jose G. Montalvo, and Marta Reynal-Querol (2008), "The curse of aid," Journal of Economic Growth 13 (3): 169-235.

Dollar, David and Aart Kraay (2003), "Institutions, trade, and growth," Journal of Monetary Economics 50 (1): 133-162.

Durlauf, Steven N., Paul A. Johnson, and Jonathan R. W. Temple (2005), "Growth Econometrics," in Philippe Aghion and Steven N. Durlauf, eds., Handbook of Economic Growth, Vol. 1B (Amsterdam: Elsevier).

Easterly, William (2009), "Can the west save Africa?" Journal of Economic Literature, 47 (2): 374-447.

Easterly, William, Ross Levine, and David M. Roodman (2004), "Aid, Policies, and Growth: Comment", American Economic Review 94 (3): 774-780.

Feyrer, James, and Bruce Sacerdote (forthcoming), "Colonialism and Modern Income," Review of Economics and Statistics 91 (2): 245-262.

Frankel , Jeffrey, and David Romer (1999), "Does Trade Cause Growth?" American Economic Review 89 (3): 379-399.

Frankel, Jeffrey, and Andrew Rose, (2002) "An Estimate of the Effect of Common Currencies on Trade and Income," Quarterly Journal of Economics 117 (2): 437-466.

Friedman, Eric, Simon Johnson, Daniel Kaufmann, and Pablo Zoido-Lobatón (2000), "Dodging the grabbing hand: the determinants of unofficial activity in 69 countries," Journal of Public Economics 76 (3): 459-493.

Forbes, Kristin (2000), "A reassessment of the relationship between inequality and growth," American Economic Review 90 (4): 869-887.

Giavazzi, Francesco and Guido Tabellini (2005), "Economic and Political Liberalizations," Journal of Monetary Economics 52 (2): 1297-1330.

Glaeser, Edward L., Rafael La Porta, Florencio López-de-Silanes, and Andrei Shleifer (2004), "Do Institutions Cause Growth?" Journal of Economic Growth 9 (3): 271-303.

Guggenberger, Patrik (2009), "The Impact of a Hausman Pretest on the Asymptotic Size of a Hypothesis Test," Econometric Theory 26 (2):369-382.

Hahn, Jinyong, John Ham, and Roger Moon (2009), "The Hausman Test and Weak Instruments," mimeo.

Hall, Alastair, Atsushi Inoue, and Changmock Shin (2008), "Entropy-Based Moment Selection in the Presence of Weak Identification," Econometric Reviews 27 (5): 398-427.

Hall, Robert and Charles I. Jones (1999), "Why Do Some Countries Produce So Much More Output per Worker Than Others?" Quarterly Journal of Economics 114 (1): 83-116.

Han, Chirok and Peter C.B. Phillips (2006), "GMM with Many Moment Conditions," Econometrica 74 (1): 147-192.

Hansen, Henrik and Finn Tarp (2001), "Aid and growth regressions," Journal of Development Economics 64(2): 547-570. 
Hauk, William and Romain Wacziarg (2009), "A Monte Carlo Study of Growth Regressions," Journal of Economic Growth 14 (2): 1381-4338.

Hausmann, Ricardo, Jason Hwang, and Dani Rodrik (2007), "What you export matters," Journal of Economic Growth 12 (1): 1-25.

Hayakawa, Kazuhiko (2007), "Small Sample Bias Properties of the System GMM Estimator in Dynamic Panel Data Models," Economics Letters 95 (1): 32-38.

Hayakawa, Kazuhiko (2009), "A Simple Efficient Instrumental Variable Estimator for Panel AR(p) Models When Both N and T are Large," Econometric Theory 25 (3): 873-890.

Holtz-Eakin, D., W. Newey, and H. S. Rosen (1988), "Estimating vector autoregressions with panel data," Econometrica 56 (6): 1371-95.

Imbens, Guido W. (2003), "Sensitivity to exogeneity assumptions in program evaluation," American Economic Review 93 (2): 126-132.

Jones, Ben, and Benjamin Olken (2005), "Do Leaders Matter? National Leadership and Growth Since World War II," Quarterly Journal of Economics 120 (3): 835-864.

Kiviet, Jan (2008), "Strength and weakness of instruments in IV and GMM estimation of dynamic panel data models," mimeo.

Kleibergen, Frank (2005), "Testing Parameters in GMM Without Assuming That They Are Identified," Econometrica 73 (4): 1103-1123.

Kleibergen, Frank and Sophocles Mavroeides (2006), "Generalized reduced rank tests using the singular value decomposition," Journal of Econometrics 133(1): 97-126.

Kleibergen, Frank and Richard Paap (2006), "Generalized reduced rank tests using the singular value decomposition," Journal of Econometrics 133(1): 97-126.

Kleibergen, Frank (2007), "Generalizing Weak Instrument Robust IV Statistics towards Multiple Parameters, Unrestricted Covariance Matrices and Identification Statistics," Journal of Econometrics 139, 181-216.

Kleibergen, Frank and Sophocles Mavroeidis (2009), "Weak Instrument Robust Tests in GMM and the New Keynesian Phillips Curve," Journal of Business and Economic Statistics 27 (2): 293-311.

Kraay, Aart (2008), "Instrumental Variables Regression with Honestly Uncertain Exclusion Restrictions," World Bank Policy Research Working Paper No. 4632.

Levine, Ross, Norman Loayza, and Thorsten Beck (2000), "Financial intermediation and growth: Causality and causes," Journal of Monetary Economics 46 (1): 31-77.

Lundberg, Mattias and Lyn Squire (2003), "The simultaneous evolution of growth and inequality," Economic Journal 113 (487): 326-344.

Mankiw, N. Gregory (1995), "The growth of nations," Brookings Papers on Economic Activity 1995 (1): $275-310$.

Mauro, Paulo (1995), "Corruption and growth," Quarterly Journal of Economics 110 (3): 681-712.

Murray, Michael P. (2006), "Avoiding invalid instruments and coping with weak instruments," Journal of Economic Perspectives 20 (4): 111-132. 
Newey, Whitney and Frank Windmeijer (2009), " Generalized Method of Moments with Many Weak Moment Conditions," Econometrica 77 (3): 687-719.

Nickell, Stephen (1981), "Biases in Dynamic Models with Fixed Effects," Econometrica 49 (4): $1417-1426$.

Noguer, Marta, and Marc Siscart (2005), "Trade raises income: a precise and more robust result," Journal of International Economics 65 (2): 447-460.

Okui, Ryo (2009), "The optimal choice of moments in dynamic panel data models," Journal of Econometrics 151 (1): 1-16.

Papaioannou, Elias and Gregorios Siourounis (2008), "Democratisation and growth," Economic Journal 118 (532): 1520-1551.

Persson, Torsten and Guido Tabellini (2006), "Democracy and Economic Development: the Devil Is In the Details," American Economic Review Papers and Proceedings 96: 319-324.

Persson, Torsten and Guido Tabellini (2007), "The Growth Effect of Democracy: Is It Heterogenous and How Can It Be Estimated?" NBER Working Paper 13150 (Cambridge, MA: National Bureau of Economic Research).

Rajan, Raghuram and Arvind Subramanian (2008), "Aid and growth: What does the cross-country evidence really show?" Review of Economics and Statistics 90 (4): 643-665.

Rodríguez, Francisco and Dani Rodrik (2001), "Trade Policy and Economic Growth: A Skeptic's Guide to the Cross-National Evidence" in Ben Bernanke and Kenneth S. Rogoff, eds., Macroeconomics Annual 2000, (Cambridge, MA: MIT Press for NBER).

Rodrik, Dani and Romain Wacziarg (2005), "Do Democratic Transitions Produce Bad Economics Outcomes?" American Economic Review Papers and Proceedings 95: 50-56.

Roodman, David (2009a), "How to Do xtabond2: An Introduction to Difference and System GMM in Stata," Stata Journal 9 (1): 86-136.

Roodman, David (2009b), "A note on the theme of too many instruments," Oxford Bulletin of Economics and Statistics 71 (1): 135-158.

Rose, Andrew K. (2006), "Size really doesn't matter: In search of a national scale effect," Journal of the Japanese and International Economies 20 (4): 482-507.

Sala-i-Martin, Xavier (1997), "I just ran two million regressions," American Economic Review 87 (2): $178-183$.

Sala-i-Martin, Xavier, Gernot Doppelhofer, and Ronald I. Miller (2004), "Determinants of longterm growth: A Bayesian averaging of classical estimates (BACE) approach," American Economic Review 94 (4): 813-835.

Spolaore, Enrico, and Romain Wacziarg (2005), "Borders and Growth," Journal of Economic Growth 10 (4): 331-386.

Stock, James H., and Jonathan H. Wright (2000), "GMM with Weak Identification," Econometrica 68 (5): 1055-1096.

Stock, James H. and Motohiro Yogo (2005), "Testing for weak instruments in linear IV regression," in J. H. Stock and D. W. K. Andrews (eds.), Identification and Inference for Econometric Models: Essays in Honor of Thomas J. Rothenberg (New York: Cambridge University Press). 
Tavares, Jose and Romain Wacziarg (2001), "How Democracy Affects Growth," European Economic Review 45 (3): 1341-1375.

Temple, Jonathan (1999), "The new growth evidence," Journal of Economic Literature 37 (1): 112-156.

Voitchovsky, Sarah (2005), "Does the Profile of Income Inequality Matter for Economic Growth?" Journal of Economic Growth 10 (3): 273-296. 


\section{Appendix A: Weak identification of nonlinear effects}

If there are diminishing returns to capital in an economy, the effect of aid on growth can be nonlinear and concave. Assuming a linear relationship can easily cloud such a relationship: the best linear fit to a concave parabola has slope zero. Beyond this clear theoretical reason to test for nonlinear effects, several important aid-growth regressions published in the past decade have tested for and found a nonlinear relationship (e.g. Hansen and Tarp 2001; Dalgaard, Hansen and Tarp 2004). In a small part of one table, Rajan and Subramanian attempt to test for a nonlinear relationship between aid and growth, but their identification strategy does not allow this. The instrumentation in these regressions is extremely weak. They do not report this.

The first row of Table A.1 shows the Cragg-Donald and Kleibergen-Paap statistics for three regressions in Rajan and Subramanian (2008) Table 4 (Panel A), where the aid effect is assumed linear. Instrumentation is strong. The next row shows the same statistics for three regressions in their Table 7 (Panel A), which include a squared aid regressor, and use $\bar{a}_{r}$ and its square as the only excluded instruments. The inclusion of the squared term causes instrumentation strength to collapse in the periods 1980-2000 and 1990-2000, which is not reported in RS. Strength is retained in the 1970-2000 period, but solely due to the presence of Guinea-Bissau in the sample for that period (Guinea-Bissau is omitted from the sample in RS's other two periods). Without Guinea-Bissau, in the third row, no useful degree of instrumentation strength is present regardless of periodization. All instrumentation in these nonlinear regressions, then, depends on a single country in a single period. The RS instrument does not allow a meaningful test of a nonlinear effect of aid on growth. ${ }^{35}$

There is no escape from this problem within the RS framework: The instruments independent of country size $\left(I_{1}-I_{7}\right)$ do not explain aid variance, and the only strong instrument (population) is plausibly invalid. The only way to advance the literature is to find new instruments - better natural experiments to isolate the true effect of aid.

Table A1: Weak instruments in nonlinear specifications

\begin{tabular}{l|lrrr}
\hline \hline Period & Test statistic & $1970-2000$ & $1980-2000$ & $1990-2000$ \\
\hline Linear specification & Cragg-Donald & 31.62 & 29.37 & 8.52 \\
(RS Table 4A) & Kleibergen-Paap & 36.13 & 31.26 & 6.95 \\
\hline Quadratic specification & Cragg-Donald & 13.70 & 0.01 & 0.14 \\
(RS Table 7A) & Kleibergen-Paap & 13.10 & 0.02 & 0.31 \\
\hline Quadratic specification & Cragg-Donald & 0.41 & 0.01 & 0.14 \\
without Guinea-Bissau * & Kleibergen-Paap & 0.28 & 0.02 & 0.31 \\
\hline \hline
\end{tabular}

* Guinea-Bissau is only included in the 1970-2000 regressions in RS.

Note that the coefficients on aid/GDP and aid/GDP squared were reported in Table 7 (Panel A) of Rajan and Subramanian (2008), but the first-stage $F$ statistics were not reported.

\footnotetext{
${ }^{35}$ One alternative procedure would be to carry out two separate zero-stage regressions, with regressands of linear aid and squared aid, to create two constructed instruments. This does not, however, improve instrumentation strength (results available on request).
} 


\section{Appendix B: Sources of additional data}

The original Rajan and Subramanian dataset was kindly provided by the authors. The analysis here required it to be supplemented with population data. The original dataset contained population ratios from zero-stage regressions but not separate figures for period-initial receiving country population. For the zero-stage regressions, the only database with sufficiently complete country coverage was the International Monetary Fund's online International Financial Statistics (accessed Sept. 9, 2007), which had populations of all aid recipient countries in the Rajan and Subramanian dataset, except for Bermuda, Kiribati, Turkmenistan, and Uzbekistan, which come from the World Bank's World Development Indicators 200\%. In the main regressions, the extreme breadth of country coverage is not needed and we took population from the Penn World Tables 6.1, since real GDP/capita came from that source. The correlation between the two sources' population estimates is near unity.

All growth determinants used in Table 6 come from the World Bank's World Development Indicators 2007 (Aid/GDP, Trade/GDP, FDI/GDP, Education Expenditure/GDP, Gini Coefficient, Government Consumption/GDP, Manufacturing Value Added/GDP, Military Personnel/Total Labor Force, Private Capital Flows/GDP, Public Debt Service/GNI, and Savings/GDP).

The Levine, Loayza and Beck (2000) dataset was obtained on 10 July 2008 from the World Bank website http://go. worldbank.org/40TPPEYOCO. 
Table 1: Second-stage cross-section regressions, 1970-2000

\begin{tabular}{lccc}
\hline \hline Dependent Variable & $\begin{array}{c}\text { Growth } \\
N=78\end{array}$ & $\begin{array}{c}\text { Growth } \\
(1)\end{array}$ & $\begin{array}{c}\text { Growth } \\
(3)\end{array}$ \\
\hline & & & \\
Aid/GDP & 0.096 & 0.911 & 0.078 \\
& $(0.070)$ & $(4.083)$ & $(0.066)$ \\
Initial Log Population & & 1.604 & \\
& & $(7.923)$ & \\
Initial GDP/capita & -1.409 & 1.061 & -1.438 \\
& $(0.435)$ & $(12.782)$ & $(0.403)$ \\
Initial Policy (Sachs-Warner) & 2.139 & 2.541 & 2.154 \\
& $(0.619)$ & $(1.981)$ & $(0.583)$ \\
Initial Life Expectancy & 0.076 & 0.368 & 0.069 \\
& $(0.039)$ & $(1.460)$ & $(0.038)$ \\
Geography & 0.606 & 0.601 & 0.581 \\
& $(0.259)$ & $(0.714)$ & $(0.249)$ \\
Institutional Quality & 4.077 & -0.041 & 4.071 \\
& $(2.328)$ & $(22.475)$ & $(2.295)$ \\
Initial Inflation & -0.005 & -0.020 & -0.005 \\
& $(0.005)$ & $(0.069)$ & $(0.004)$ \\
Initial M2/GDP & 0.010 & 0.006 & 0.011 \\
& $(0.020)$ & $(0.058)$ & $(0.019)$ \\
Initial Budget Balance/GDP & 0.016 & 0.117 & 0.012 \\
& $(0.036)$ & $(0.488)$ & $(0.035)$ \\
Revolutions & -1.406 & -4.567 & -1.395 \\
& $(0.656)$ & $(16.113)$ & $(0.625)$ \\
Ethnic Fractionalization & 0.788 & 4.518 & 0.658 \\
& $(0.851)$ & $(18.927)$ & $(0.820)$ \\
Constant & 5.505 & -56.789 & 6.163 \\
& $(3.527)$ & $(312.142)$ & $(3.102)$ \\
& & & \\
\hline Excluded Instrument & $\bar{a}_{r}$ & $\bar{a}_{r}$ & $\ln (\mathrm{pop})$ \\
Cragg-Donald $F$ stat ${ }^{\dagger}$ & 31.63 & 0.13 & 36.30 \\
Kleibergen-Paap $F$ stat ${ }^{\dagger}$ & 36.13 & 0.07 & 32.14 \\
Kleibergen-Paap LM test (p-val) & $<0.01$ & 0.77 & $<0.01$ \\
\hline \hline
\end{tabular}

$\dagger$ In this special case of a single endogenous regressor, the Cragg-Donald and Kleibergen-Paap $F$ statistics reduce respectively to the standard non-robust and robust first-stage $F$ statistics. Heteroskedasticity-robust standard errors in parentheses. All specifications include dummies for sub-Saharan Africa and East Asia. 
Table 2: Instrumentation strength in cross-section regressions

\begin{tabular}{|c|c|c|c|c|}
\hline \multicolumn{2}{|c|}{ "Zero-Stage" Specification } & $\begin{array}{c}\text { Replication } \\
\text { (1) }\end{array}$ & $\begin{array}{l}\text { Colonial } \\
\text { variables only } \\
\text { (2) }\end{array}$ & $\begin{array}{l}\text { Population } \\
\text { variables only } \\
\text { (3) }\end{array}$ \\
\hline \multirow{3}{*}{$\begin{array}{l}1970-2000 \\
(N=78)\end{array}$} & Cragg-Donald $F$ stat & 31.63 & $<0.01$ & 35.90 \\
\hline & Kleibergen-Paap $F$ stat & 36.13 & $<0.01$ & 31.62 \\
\hline & Kleibergen-Paap LM test (p-val) & $<0.01$ & 0.98 & $<0.01$ \\
\hline \multirow{3}{*}{$\begin{array}{l}1980-2000 \\
(N=75)\end{array}$} & Cragg-Donald $F$ stat & 29.37 & 1.41 & 40.54 \\
\hline & Kleibergen-Paap $F$ stat & 31.26 & 1.41 & 39.65 \\
\hline & Kleibergen-Paap LM test (p-val) & $<0.01$ & 0.28 & $<0.01$ \\
\hline \multirow{3}{*}{$\begin{array}{l}1990-2000 \\
(N=70)\end{array}$} & Cragg-Donald $F$ stat & 8.52 & 1.69 & 12.86 \\
\hline & Kleibergen-Paap $F$ stat & 6.95 & 1.18 & 9.00 \\
\hline & Kleibergen-Paap LM test (p-val) & $<0.01$ & 0.29 & $<0.01$ \\
\hline
\end{tabular}

$\dagger$ In this special case of a single endogenous regressor, the Cragg-Donald and Kleibergen-Paap $F$ statistics reduce respectively to the standard non-robust and robust first-stage $F$ statistics. 


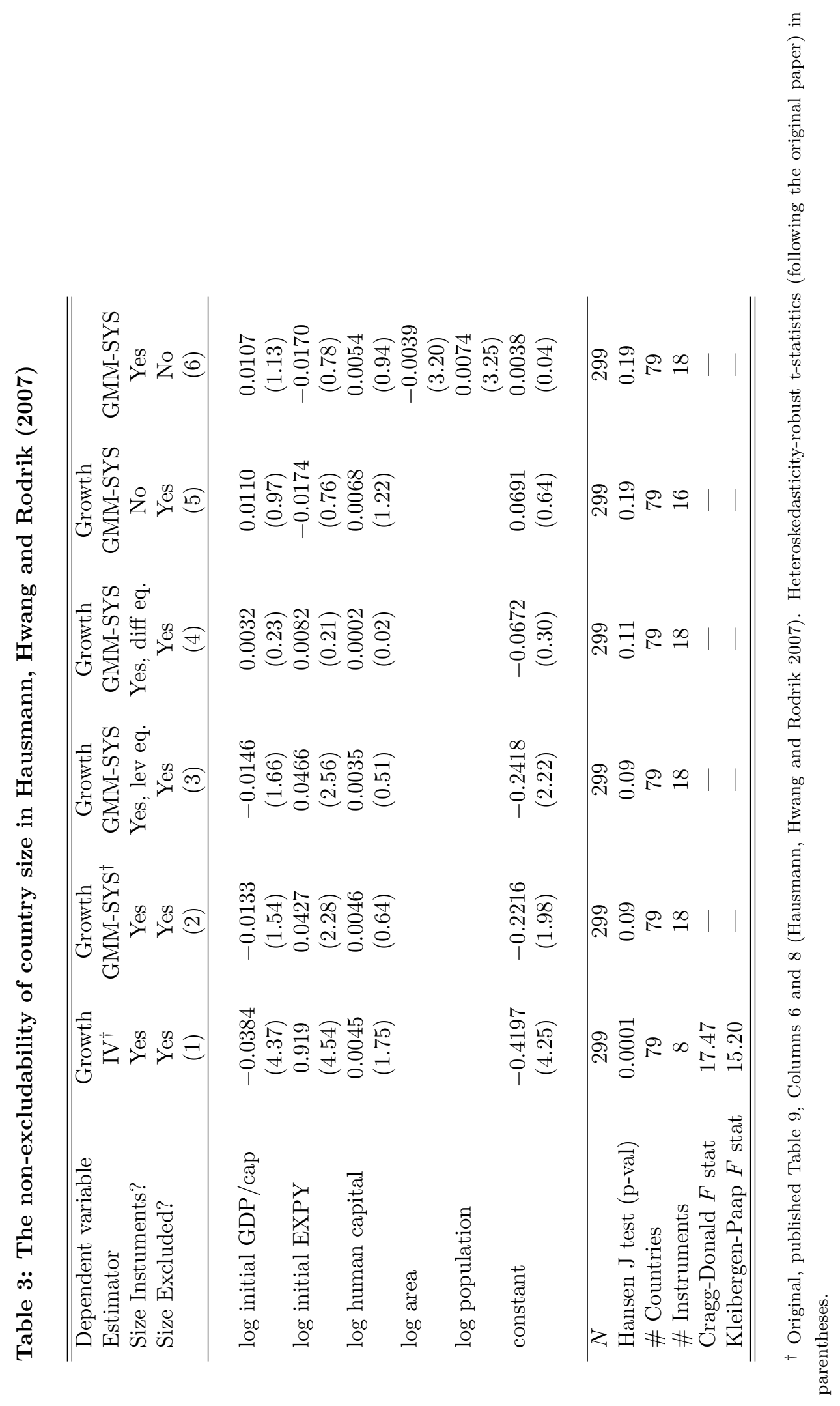


Table 4: Partial regression coefficients when ln Population is regressed on other growth determinants and RS covariates, 1970-2000 cross-section.

\begin{tabular}{lrcc}
\hline \hline Dependent Variable & ln Population regressor & \\
& Coefficient & Std. err. & $N$ \\
\hline Aid/GDP & -1.925 & 0.340 & 78 \\
Trade/GDP & -13.680 & 2.497 & 77 \\
FDI/GDP & -0.537 & 0.183 & 77 \\
Education Expenditure/GDP & -0.423 & 0.179 & 75 \\
Gini Coefficient & -2.452 & 0.991 & 62 \\
Government Consumption/GDP & -1.399 & 0.352 & 78 \\
Manufacturing Value Added/GDP & 1.529 & 0.398 & 76 \\
Military Personnel/Total Labor Force & -0.263 & 0.123 & 78 \\
Private Capital Flows/GDP & -2.548 & 1.057 & 77 \\
Public Debt Service/GNI & -0.396 & 0.229 & 73 \\
Savings/GDP & 3.245 & 1.502 & 78 \\
\hline \hline
\end{tabular}

Heteroskedasticity-robust standard errors in parentheses. The point estimates and standard errors on the additional right hand side covariates have been omitted, but are available upon request. 
Table 5a: Weak instruments in Levine, Loayza, and Beck (2000)

\begin{tabular}{|c|c|c|c|c|c|}
\hline $\begin{array}{l}\text { Dependent variable } \\
\text { Estimator } \\
\text { Collapsed IV Matrix }\end{array}$ & $\begin{array}{c}\text { Growth } \\
\text { GMM-SYS }^{\dagger} \\
\text { No } \\
(1) \\
\end{array}$ & $\begin{array}{c}\text { Growth } \\
\text { GMM-SYS } \\
\text { No } \\
(2) \\
\end{array}$ & $\begin{array}{c}\text { Growth } \\
\text { OLS } \\
\text { No } \\
(3) \\
\end{array}$ & $\begin{array}{c}\text { Growth } \\
\text { OLS-FD } \\
\text { No } \\
(4) \\
\end{array}$ & $\begin{array}{c}\text { Growth } \\
\text { OLS-FE } \\
\text { No } \\
(5) \\
\end{array}$ \\
\hline Liquid liabilities & $\begin{array}{c}2.952 \\
(0.001)\end{array}$ & $\begin{array}{c}3.030 \\
(0.002)\end{array}$ & $\begin{array}{c}1.687 \\
(0.000)\end{array}$ & $\begin{array}{c}0.876 \\
(0.221)\end{array}$ & $\begin{array}{c}0.738 \\
(0.356)\end{array}$ \\
\hline Log initial GDP/capita & $\begin{array}{l}-0.742 \\
(0.001)\end{array}$ & $\begin{array}{l}-0.263 \\
(0.698)\end{array}$ & $\begin{array}{l}-0.353 \\
(0.047)\end{array}$ & $\begin{array}{c}-13.235 \\
(0.000)\end{array}$ & $\begin{array}{l}-7.312 \\
(0.000)\end{array}$ \\
\hline Government size & $\begin{array}{l}-1.341 \\
(0.001)\end{array}$ & $\begin{array}{c}0.025 \\
(0.988)\end{array}$ & $\begin{array}{l}-1.110 \\
(0.033)\end{array}$ & $\begin{array}{l}-1.881 \\
(0.125)\end{array}$ & $\begin{array}{l}-1.986 \\
(0.150)\end{array}$ \\
\hline Openness to trade & $\begin{array}{c}0.325 \\
(0.169)\end{array}$ & $\begin{array}{l}-0.187 \\
(0.839)\end{array}$ & $\begin{array}{c}0.243 \\
(0.427)\end{array}$ & $\begin{array}{c}1.138 \\
(0.448)\end{array}$ & $\begin{array}{c}0.646 \\
(0.645)\end{array}$ \\
\hline Inflation & $\begin{array}{c}1.748 \\
(0.001)\end{array}$ & $\begin{array}{c}1.274 \\
(0.390)\end{array}$ & $\begin{array}{l}-0.009 \\
(0.992)\end{array}$ & $\begin{array}{l}-3.368 \\
(0.001)\end{array}$ & $\begin{array}{l}-3.502 \\
(0.000)\end{array}$ \\
\hline Avg yrs secondary school & $\begin{array}{c}0.780 \\
(0.001)\end{array}$ & $\begin{array}{l}-0.122 \\
(0.851)\end{array}$ & $\begin{array}{c}0.447 \\
(0.238)\end{array}$ & $\begin{array}{c}0.100 \\
(0.824)\end{array}$ & $\begin{array}{c}0.939 \\
(0.155)\end{array}$ \\
\hline Black market premium & $\begin{array}{l}-2.076 \\
(0.001)\end{array}$ & $\begin{array}{l}-2.313 \\
(0.000)\end{array}$ & $\begin{array}{l}-1.530 \\
(0.000)\end{array}$ & $\begin{array}{l}-0.542 \\
(0.319)\end{array}$ & $\begin{array}{l}-0.426 \\
(0.478)\end{array}$ \\
\hline Constant & $\begin{array}{c}0.060 \\
(0.954)\end{array}$ & $\begin{array}{l}-4.516 \\
(0.409)\end{array}$ & $\begin{array}{l}-1.202 \\
(0.470)\end{array}$ & & $\begin{array}{l}56.028 \\
(0.000)\end{array}$ \\
\hline$N$ & 353 & 353 & 353 & 328 & 353 \\
\hline \# Countries & - & 77 & 77 & 77 & 77 \\
\hline \# Instruments & - & 75 & - & - & - \\
\hline IV: Lagged Levels & Yes & Yes & - & - & - \\
\hline IV: Lagged Diffs & Yes & Yes & - & - & - \\
\hline Cragg-Donald $F$ stat & - & - & - & - & - \\
\hline Kleibergen-Paap $F$ stat & - & - & - & 一 & - \\
\hline Kleibergen-Paap LM test (p-val) & - & - & - & - & - \\
\hline
\end{tabular}

We follow the original paper in reporting p-values in parentheses. ${ }^{\dagger}$ Original, published Table 5, Column 1 (Levine,




Table 5b: Weak instruments in Levine, Loayza, and Beck (2000), continued

\begin{tabular}{|c|c|c|c|c|}
\hline "Dependent variable & $\begin{array}{l}\text { Growth } \\
\text { Difference }\end{array}$ & $\begin{array}{l}\text { Growth } \\
\text { Equation }\end{array}$ & \multicolumn{2}{|c|}{ Levels Equation } \\
\hline Estimator & 2SLS & 2SLS & 2SLS & 2SLS \\
\hline Collapsed IV Matrix & $\begin{array}{l}\text { No } \\
(6)\end{array}$ & $\begin{array}{l}\text { Yes } \\
(7)\end{array}$ & $\begin{array}{l}\text { No } \\
(8)\end{array}$ & $\begin{array}{l}\text { Yes } \\
(9)\end{array}$ \\
\hline Liquid liabilities & $\begin{array}{l}-1.208 \\
(0.549)\end{array}$ & $\begin{array}{c}-12.398 \\
(0.712)\end{array}$ & $\begin{array}{c}2.733 \\
(0.011)\end{array}$ & $\begin{array}{c}1.963 \\
(0.423)\end{array}$ \\
\hline Log initial GDP/capita & $\begin{array}{c}-12.243 \\
(0.000)\end{array}$ & $\begin{array}{c}-10.754 \\
(0.206)\end{array}$ & $\begin{array}{c}0.647 \\
(0.335)\end{array}$ & $\begin{array}{c}2.293 \\
(0.325)\end{array}$ \\
\hline Government size & $\begin{array}{c}0.052 \\
(0.980)\end{array}$ & $\begin{array}{c}8.622 \\
(0.481)\end{array}$ & $\begin{array}{l}-2.140 \\
(0.126)\end{array}$ & $\begin{array}{l}-8.899 \\
(0.204)\end{array}$ \\
\hline Openness to trade & $\begin{array}{c}2.817 \\
(0.189)\end{array}$ & $\begin{array}{c}0.511 \\
(0.901)\end{array}$ & $\begin{array}{l}-0.417 \\
(0.718)\end{array}$ & $\begin{array}{c}6.629 \\
(0.404)\end{array}$ \\
\hline Inflation & $\begin{array}{l}-1.353 \\
(0.669)\end{array}$ & $\begin{array}{c}-34.177 \\
(0.513)\end{array}$ & $\begin{array}{l}-1.031 \\
(0.581)\end{array}$ & $\begin{array}{l}2.822 \\
(0.487)\end{array}$ \\
\hline Avg yrs secondary school & $\begin{array}{c}0.959 \\
(0.509)\end{array}$ & $\begin{array}{c}-7.874 \\
(0.663)\end{array}$ & $\begin{array}{l}-1.047 \\
(0.150)\end{array}$ & $\begin{array}{l}-2.429 \\
(0.325)\end{array}$ \\
\hline Black market premium & $\begin{array}{l}-0.408 \\
(0.664)\end{array}$ & $\begin{array}{c}2.455 \\
(0.814)\end{array}$ & $\begin{array}{l}-1.926 \\
(0.003)\end{array}$ & $\begin{array}{r}-0.340 \\
(0.878)\end{array}$ \\
\hline Constant & & & $\begin{array}{l}-4.769 \\
(0.389)\end{array}$ & $\begin{array}{c}-24.238 \\
(0.269)\end{array}$ \\
\hline$N$ & 328 & 328 & 353 & 353 \\
\hline \# Countries & 77 & 77 & 77 & 77 \\
\hline \# Instruments & 40 & 12 & 40 & 12 \\
\hline IV: Lagged Levels & Yes & Yes & No & No \\
\hline IV: Lagged Diffs & No & No & Yes & Yes \\
\hline Cragg-Donald $F$ stat & 0.57 & 0.05 & 0.62 & 0.23 \\
\hline Kleibergen-Paap $F$ stat & 1.75 & 0.57 & 1.45 & 0.23 \\
\hline Kleibergen-Paap LM test (p-val) & 0.22 & 0.57 & 0.81 & 0.21 \\
\hline
\end{tabular}

We follow the original paper in reporting $\mathrm{p}$-values in parentheses. 
Table 6a: Weak instruments in Rajan and Subramanian (2008)

\begin{tabular}{|c|c|c|c|c|c|}
\hline $\begin{array}{l}\text { Dependent variable } \\
\text { Estimator } \\
\text { Collapsed IV Matrix }\end{array}$ & $\begin{array}{c}\text { Growth } \\
\text { GMM-DIF }^{\dagger} \\
\text { No } \\
(1) \\
\end{array}$ & $\begin{array}{c}\text { Growth } \\
\text { GMM-SYS }^{\dagger} \\
\text { No } \\
(2) \\
\end{array}$ & $\begin{array}{c}\text { Growth } \\
\text { OLS } \\
\text { No } \\
(3) \\
\end{array}$ & $\begin{array}{c}\text { Growth } \\
\text { OLS-FD } \\
\text { No } \\
(4) \\
\end{array}$ & $\begin{array}{c}\text { Growth } \\
\text { OLS-FE } \\
\text { No } \\
(5) \\
\end{array}$ \\
\hline Aid/GDP & $\begin{array}{l}-0.151 \\
(0.077)\end{array}$ & $\begin{array}{l}-0.054 \\
(0.114)\end{array}$ & $\begin{array}{l}-0.037 \\
(0.053)\end{array}$ & $\begin{array}{l}-0.236 \\
(0.066)\end{array}$ & $\begin{array}{c}-0.262 \\
(0.067)\end{array}$ \\
\hline Initial GDP/capita & $\begin{array}{l}-8.347 \\
(1.543)\end{array}$ & $\begin{array}{l}-2.456 \\
(1.057)\end{array}$ & $\begin{array}{l}-1.514 \\
(0.517)\end{array}$ & $\begin{array}{c}-13.245 \\
(1.839)\end{array}$ & $\begin{array}{l}-7.960 \\
(1.307)\end{array}$ \\
\hline Policy & $\begin{array}{l}-1.774 \\
(0.933)\end{array}$ & $\begin{array}{l}1.370 \\
(1.015)\end{array}$ & $\begin{array}{c}0.428 \\
(0.587)\end{array}$ & $\begin{array}{l}-1.131 \\
(0.535)\end{array}$ & $\begin{array}{l}-1.062 \\
(0.660)\end{array}$ \\
\hline Life Expectancy & $\begin{array}{l}-0.393 \\
(0.183)\end{array}$ & $\begin{array}{c}0.086 \\
(0.098)\end{array}$ & $\begin{array}{c}0.049 \\
(0.067)\end{array}$ & $\begin{array}{l}-0.136 \\
(0.132)\end{array}$ & $\begin{array}{l}-0.082 \\
(0.117)\end{array}$ \\
\hline Institutional Qual. & $\begin{array}{c}6.953 \\
(2.767)\end{array}$ & $\begin{array}{c}2.748 \\
(2.579)\end{array}$ & $\begin{array}{c}2.961 \\
(1.561)\end{array}$ & $\begin{array}{c}6.409 \\
(1.789)\end{array}$ & $\begin{array}{c}4.245 \\
(1.901)\end{array}$ \\
\hline Log Inflation & $\begin{array}{l}-1.985 \\
(0.671)\end{array}$ & $\begin{array}{l}-1.498 \\
(0.663)\end{array}$ & $\begin{array}{l}-1.854 \\
(0.489)\end{array}$ & $\begin{array}{l}-1.742 \\
(0.409)\end{array}$ & $\begin{array}{c}-1.916 \\
(0.440)\end{array}$ \\
\hline M2/GDP & $\begin{array}{l}-0.002 \\
(0.032)\end{array}$ & $\begin{array}{c}0.010 \\
(0.021)\end{array}$ & $\begin{array}{l}-0.004 \\
(0.015)\end{array}$ & $\begin{array}{l}-0.001 \\
(0.039)\end{array}$ & $\begin{array}{l}-0.007 \\
(0.032)\end{array}$ \\
\hline Budget Bal./GDP & $\begin{array}{c}0.164 \\
(0.082)\end{array}$ & $\begin{array}{c}0.101 \\
(0.075)\end{array}$ & $\begin{array}{c}0.100 \\
(0.063)\end{array}$ & $\begin{array}{c}0.184 \\
(0.057)\end{array}$ & $\begin{array}{c}0.106 \\
(0.059)\end{array}$ \\
\hline Revolutions & $\begin{array}{l}-0.972 \\
(0.625)\end{array}$ & $\begin{array}{l}-0.073 \\
(0.992)\end{array}$ & $\begin{array}{l}-0.487 \\
(0.374)\end{array}$ & $\begin{array}{l}-1.104 \\
(0.559)\end{array}$ & $\begin{array}{l}-1.049 \\
(0.517)\end{array}$ \\
\hline Ethnic Frac. & & $\begin{array}{c}0.129 \\
(1.809)\end{array}$ & $\begin{array}{c}0.173 \\
(1.114)\end{array}$ & & \\
\hline Geography & & $\begin{array}{c}0.496 \\
(0.353)\end{array}$ & $\begin{array}{c}0.522 \\
(0.276)\end{array}$ & & \\
\hline$N$ & 167 & 239 & 239 & 167 & 239 \\
\hline \# of countries & 68 & 72 & 72 & 68 & 72 \\
\hline \# of instruments & 120 & 158 & - & - & - \\
\hline Lags used & $2-7$ & $2-7$ & - & - & - \\
\hline IV: Lagged levels & Yes & Yes & No & No & No \\
\hline IV: Lagged diffs & No & Yes & No & No & No \\
\hline Cragg-Donald $F$ stat & - & - & - & - & - \\
\hline Kleibergen-Paap $F$ stat & - & - & - & - & - \\
\hline Kleibergen-Paap LM test (p-val) & - & - & - & - & - \\
\hline
\end{tabular}

${ }^{\dagger}$ Exact replication of original published Table 9, Column 1 and Table 10, Column 1 respectively. Heteroskedasticityrobust standard errors in parentheses. Following Rajan and Subramanian, we include but suppress the point estimates on a constant and dummies for Sub-Saharan Africa and East Asia in columns 2, 3, 5, 8 and 9. 
Table 6b: Weak instruments in Rajan and Subramanian (2008), continued

\begin{tabular}{|c|c|c|c|c|}
\hline \multirow{3}{*}{$\begin{array}{l}\text { Dependent variable } \\
\text { Estimator } \\
\text { Collapsed IV Matrix }\end{array}$} & \multicolumn{2}{|c|}{$\begin{array}{l}\text { Growth Growth } \\
\text { Difference Equation }\end{array}$} & \multicolumn{2}{|c|}{$\begin{array}{c}\text { Growth Growth } \\
\text { Levels Equation }\end{array}$} \\
\hline & 2SLS & 2SLS & 2SLS & 2SLS \\
\hline & $\begin{array}{l}\text { No } \\
(6)\end{array}$ & $\begin{array}{l}\text { Yes } \\
(7)\end{array}$ & $\begin{array}{l}\text { No } \\
(8)\end{array}$ & $\begin{array}{l}\text { Yes } \\
(9)\end{array}$ \\
\hline Aid/GDP & $\begin{array}{l}-0.220 \\
(0.071)\end{array}$ & $\begin{array}{l}-0.355 \\
(0.123)\end{array}$ & $\begin{array}{c}0.116 \\
(0.089)\end{array}$ & $\begin{array}{c}0.470 \\
(0.854)\end{array}$ \\
\hline Initial GDP/capita & $\begin{array}{c}-11.060 \\
(1.644)\end{array}$ & $\begin{array}{c}-10.535 \\
(2.295)\end{array}$ & $\begin{array}{c}0.117 \\
(1.307)\end{array}$ & $\begin{array}{c}10.193 \\
(18.102)\end{array}$ \\
\hline Policy & $\begin{array}{l}-1.515 \\
(0.696)\end{array}$ & $\begin{array}{l}-1.869 \\
(0.887)\end{array}$ & $\begin{array}{l}-0.095 \\
(0.816)\end{array}$ & $\begin{array}{c}5.429 \\
(6.634)\end{array}$ \\
\hline Life Expectancy & $\begin{array}{l}-0.369 \\
(0.147)\end{array}$ & $\begin{array}{l}-0.232 \\
(0.185)\end{array}$ & $\begin{array}{c}0.014 \\
(0.159)\end{array}$ & $\begin{array}{l}-2.086 \\
(2.549)\end{array}$ \\
\hline Institutional Qual. & $\begin{array}{c}6.537 \\
(1.864)\end{array}$ & $\begin{array}{c}6.570 \\
(3.098)\end{array}$ & $\begin{array}{c}4.356 \\
(3.560)\end{array}$ & $\begin{array}{c}34.008 \\
(96.093)\end{array}$ \\
\hline Log Inflation & $\begin{array}{l}-1.921 \\
(0.424)\end{array}$ & $\begin{array}{l}-1.120 \\
(0.840)\end{array}$ & $\begin{array}{l}-1.927 \\
(0.902)\end{array}$ & $\begin{array}{l}-2.168 \\
(4.999)\end{array}$ \\
\hline $\mathrm{M} 2 / \mathrm{GDP}$ & $\begin{array}{l}-0.002 \\
(0.039)\end{array}$ & $\begin{array}{l}-0.025 \\
(0.052)\end{array}$ & $\begin{array}{c}0.018 \\
(0.028)\end{array}$ & $\begin{array}{l}-0.015 \\
(0.109)\end{array}$ \\
\hline Budget Bal./GDP & $\begin{array}{c}0.246 \\
(0.066)\end{array}$ & $\begin{array}{c}0.354 \\
(0.110)\end{array}$ & $\begin{array}{c}0.014 \\
(0.156)\end{array}$ & $\begin{array}{c}0.422 \\
(0.948)\end{array}$ \\
\hline Revolutions & $\begin{array}{l}-1.072 \\
(0.697)\end{array}$ & $\begin{array}{l}-1.396 \\
(0.962)\end{array}$ & $\begin{array}{c}0.032 \\
(1.159)\end{array}$ & $\begin{array}{l}1.436 \\
(7.369)\end{array}$ \\
\hline Ethnic Frac. & & & $\begin{array}{c}0.570 \\
(1.407)\end{array}$ & $\begin{array}{l}-2.196 \\
(6.256)\end{array}$ \\
\hline Geography & & & $\begin{array}{c}0.333 \\
(0.360)\end{array}$ & $\begin{array}{l}-0.339 \\
(3.114)\end{array}$ \\
\hline$N$ & 167 & 167 & 239 & 239 \\
\hline \# of countries & 68 & 68 & 72 & 72 \\
\hline \# of instruments & 120 & 52 & 41 & 17 \\
\hline Lags used & $2-7$ & $2-7$ & 2 & 2 \\
\hline IV: Lagged levels & Yes & Yes & No & No \\
\hline IV: Lagged diffs & No & No & Yes & Yes \\
\hline Cragg-Donald $F$ stat & 0.66 & 0.43 & 0.41 & 0.06 \\
\hline Kleibergen-Paap $F$ stat & 9.89 & 3.83 & 0.99 & 0.05 \\
\hline Kleibergen-Paap LM test (p-val) & 0.52 & 0.23 & 0.82 & 0.47 \\
\hline
\end{tabular}




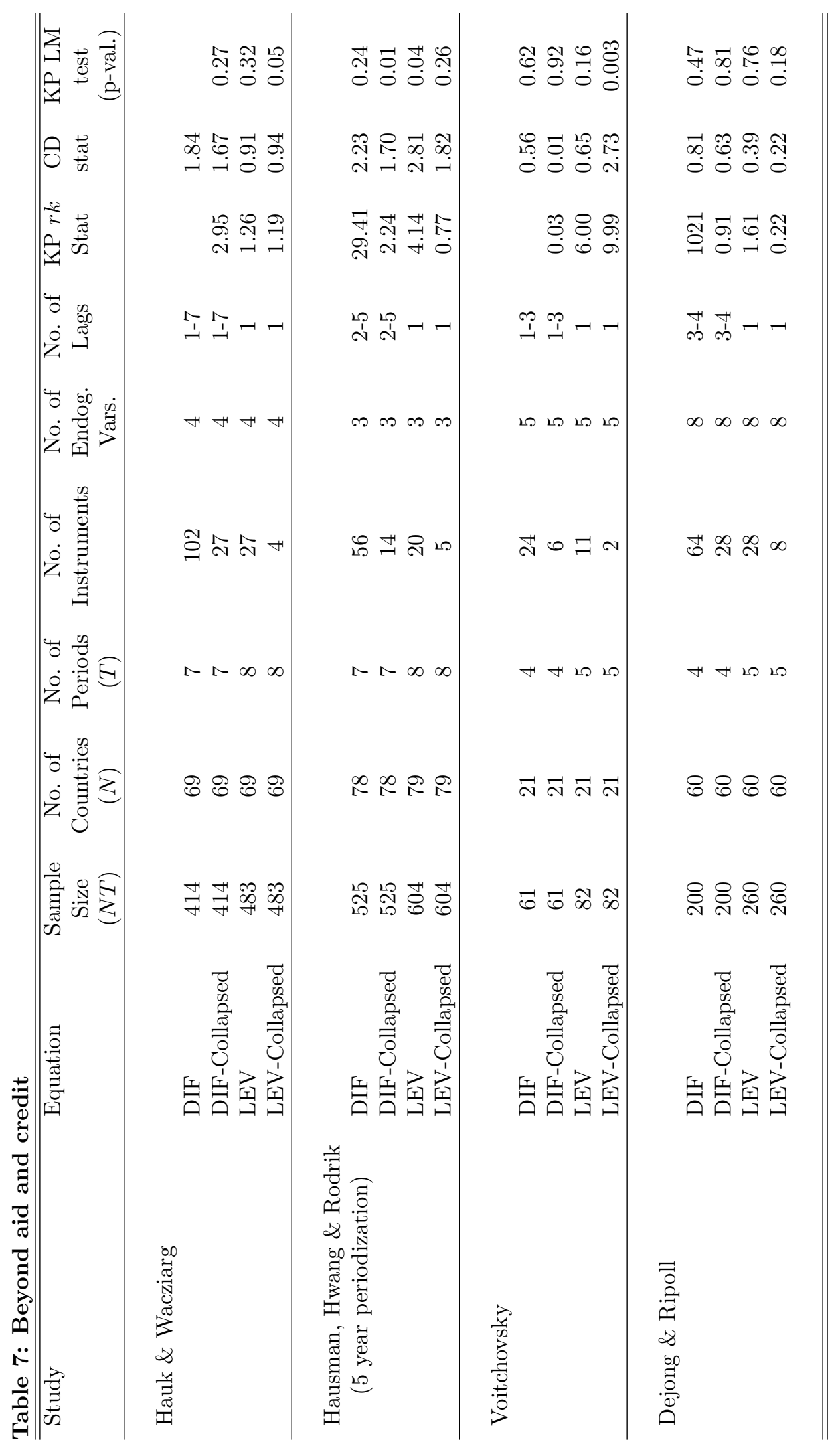


Figure 1: Power and size properties of GMM estimators in simulation results, $\beta=0.2$

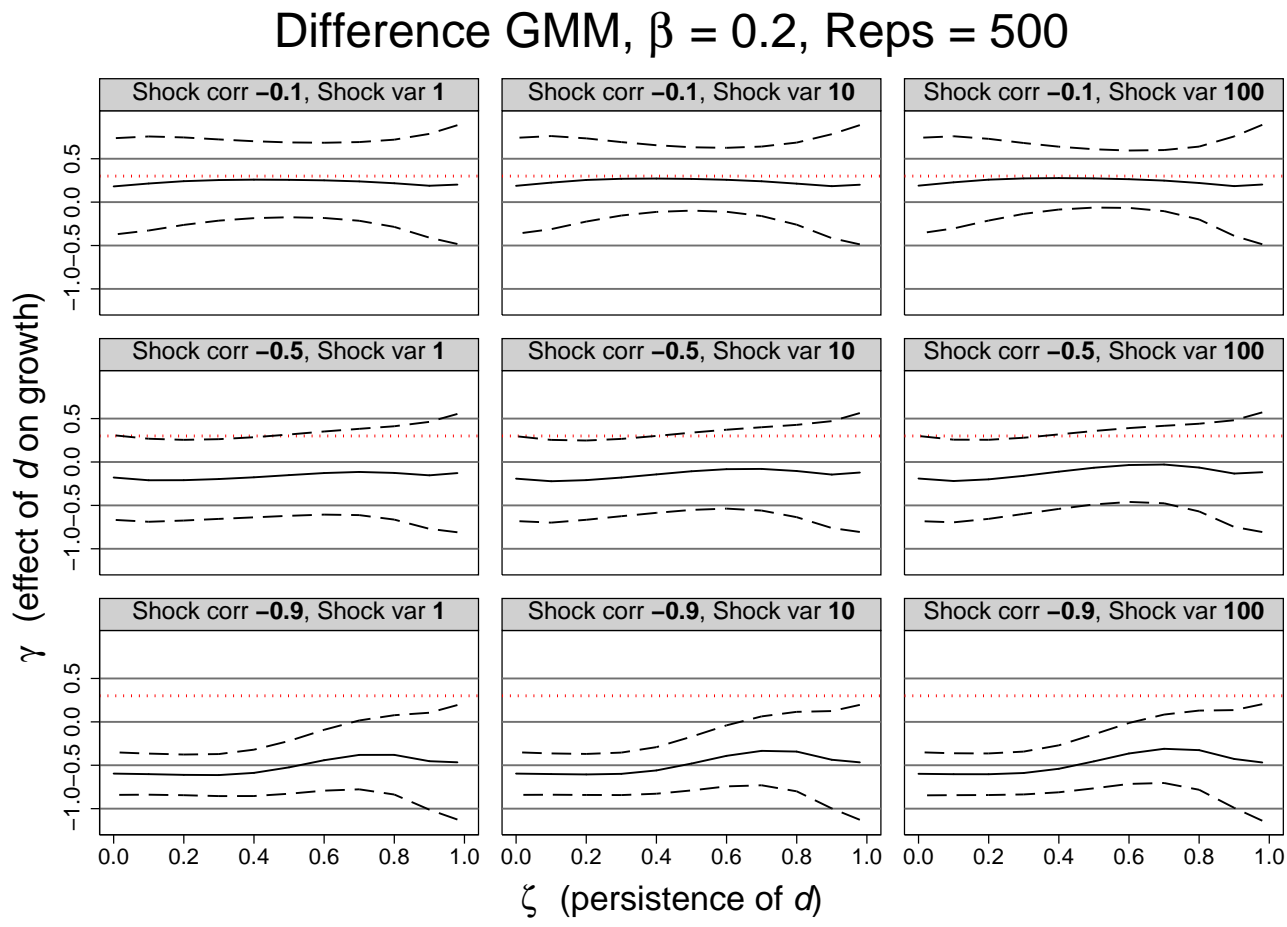

System GMM, $\beta=0.2$, Reps $=500$

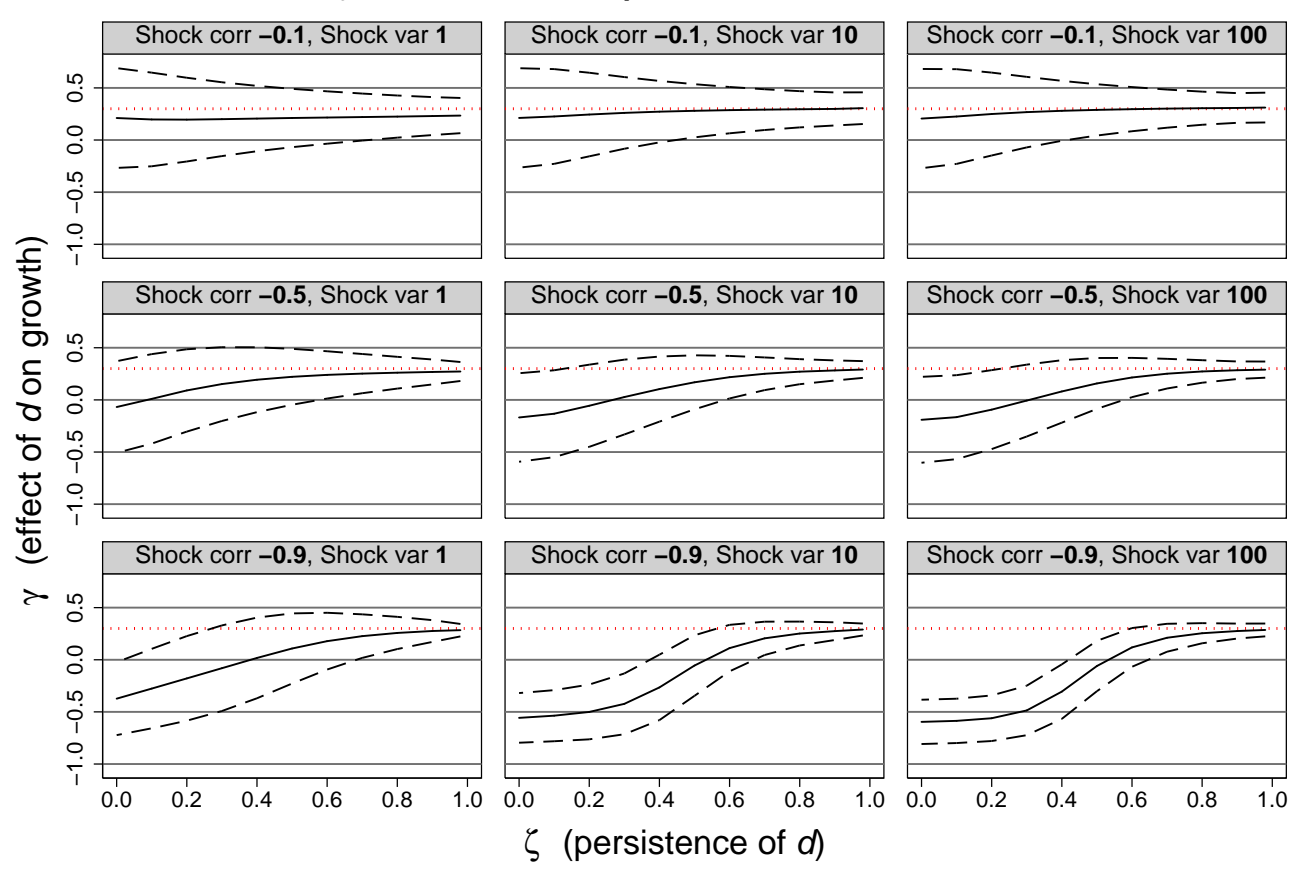


Figure 2: Weak identification in simulation results, $\beta=0.2$

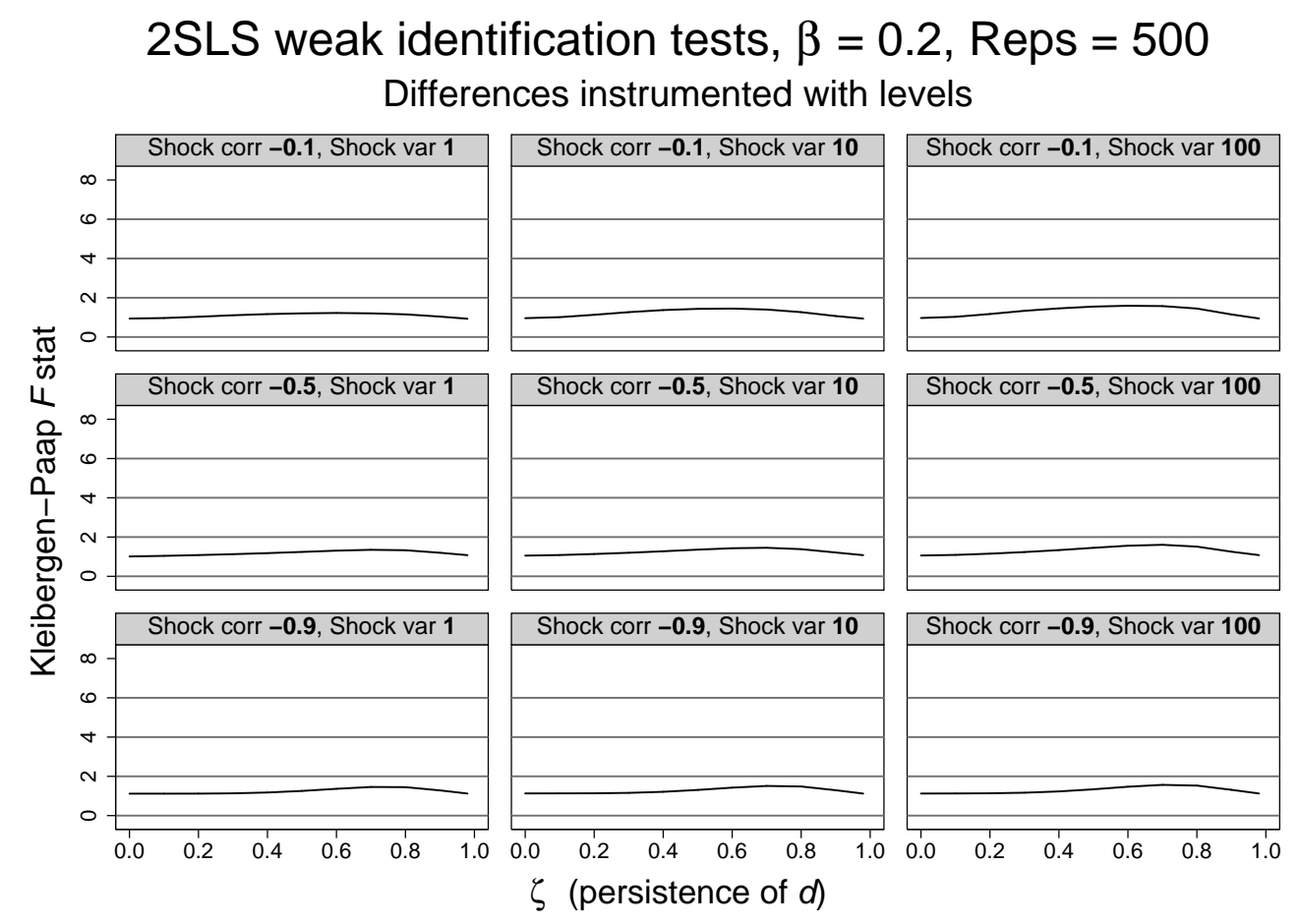

2SLS weak identification tests, $\beta=0.2$, Reps $=500$ Levels instrumented with differences

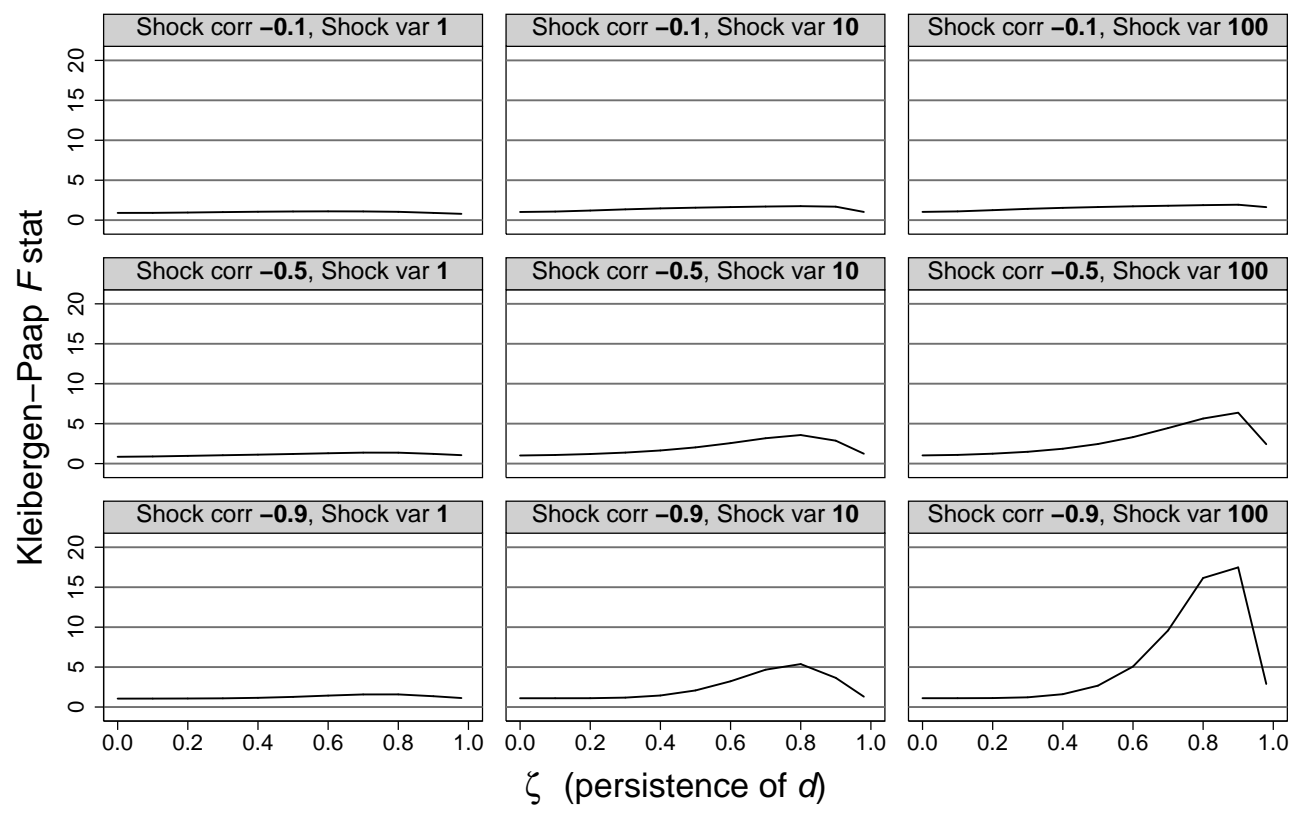


Figure 3: Power and size properties of GMM estimators in simulation results, $\beta=0.8$

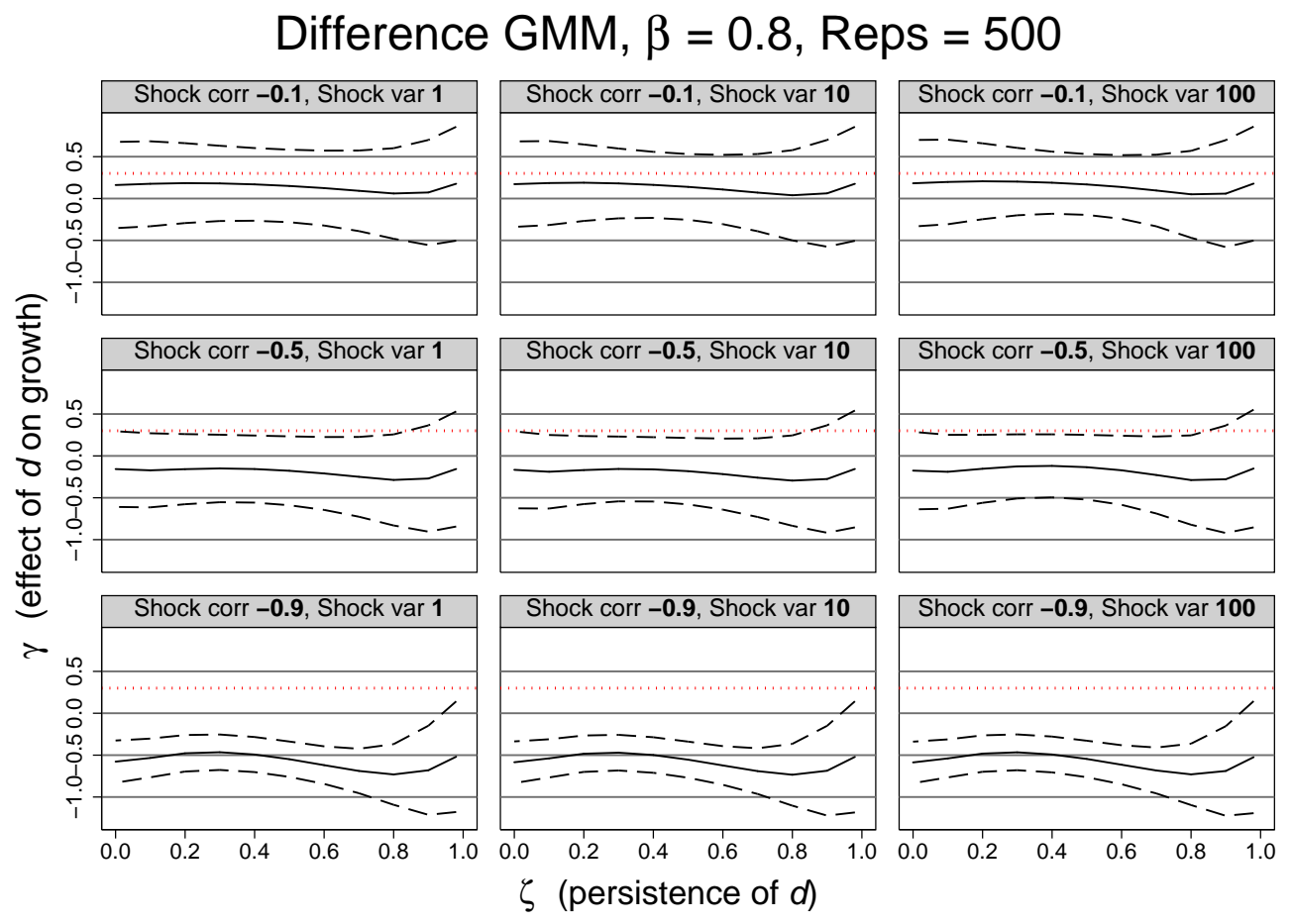

System GMM, $\beta=0.8$, Reps $=500$

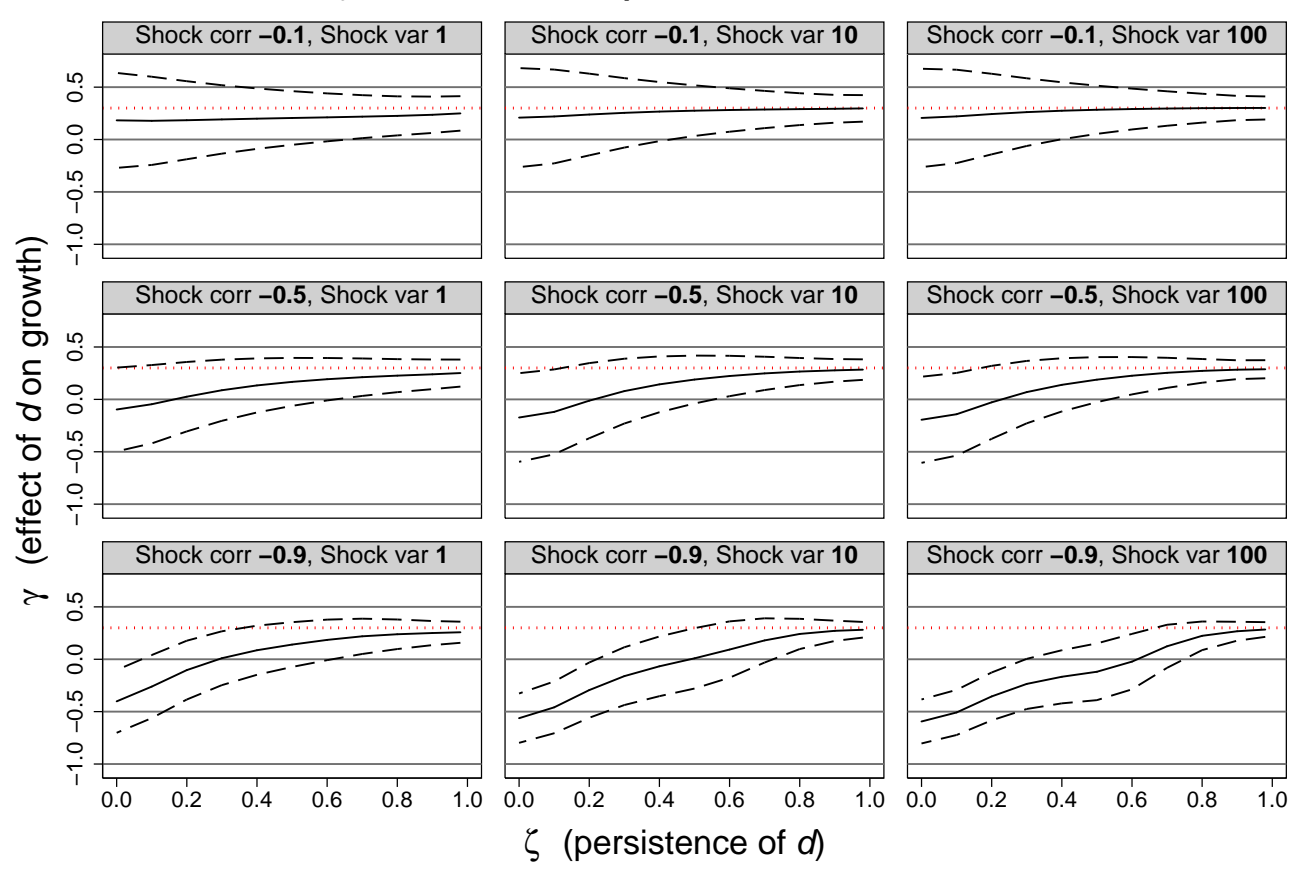


Figure 4: Weak identification in simulation results, $\beta=0.8$

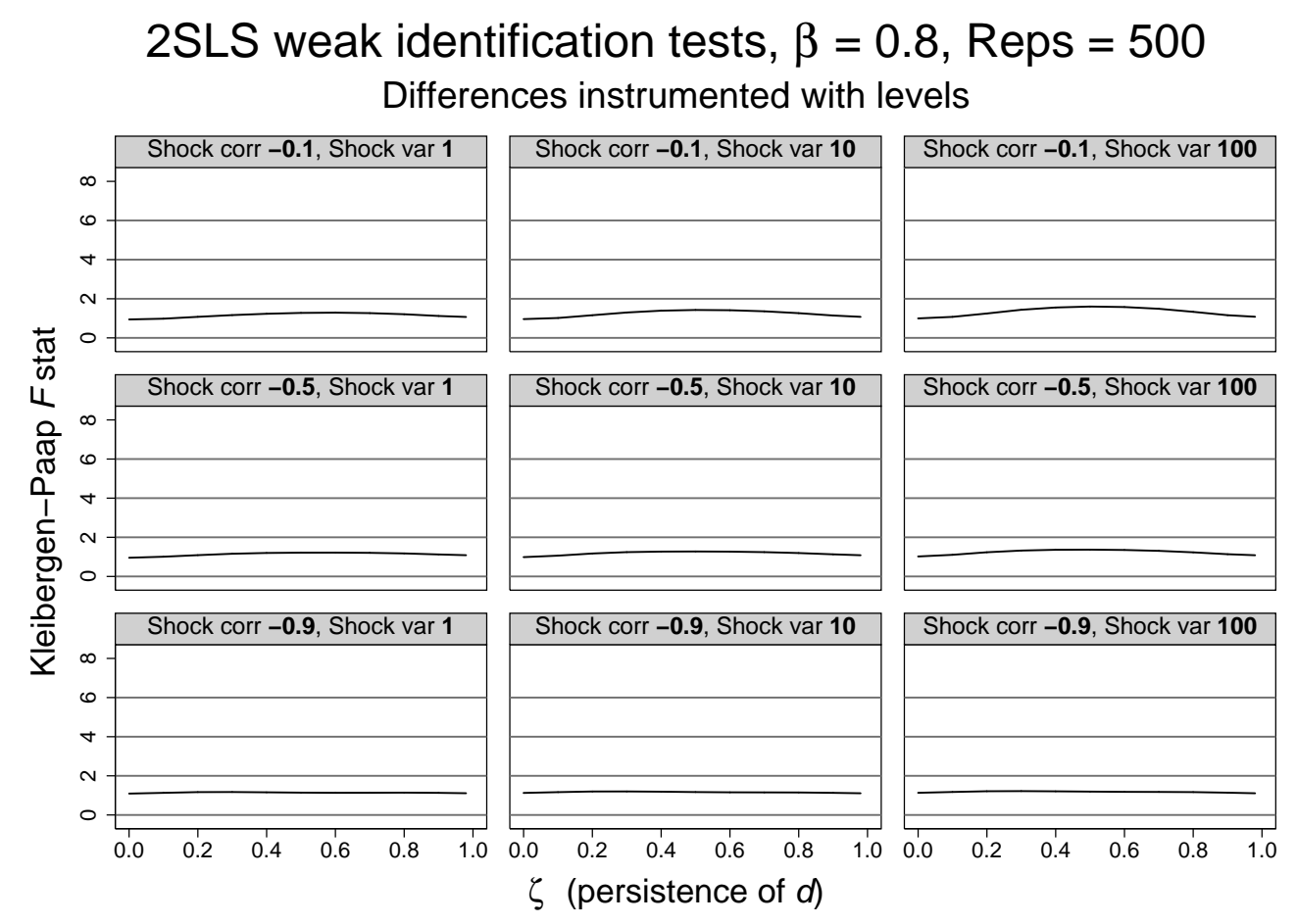

2SLS weak identification tests, $\beta=0.8$, Reps $=500$ Levels instrumented with differences

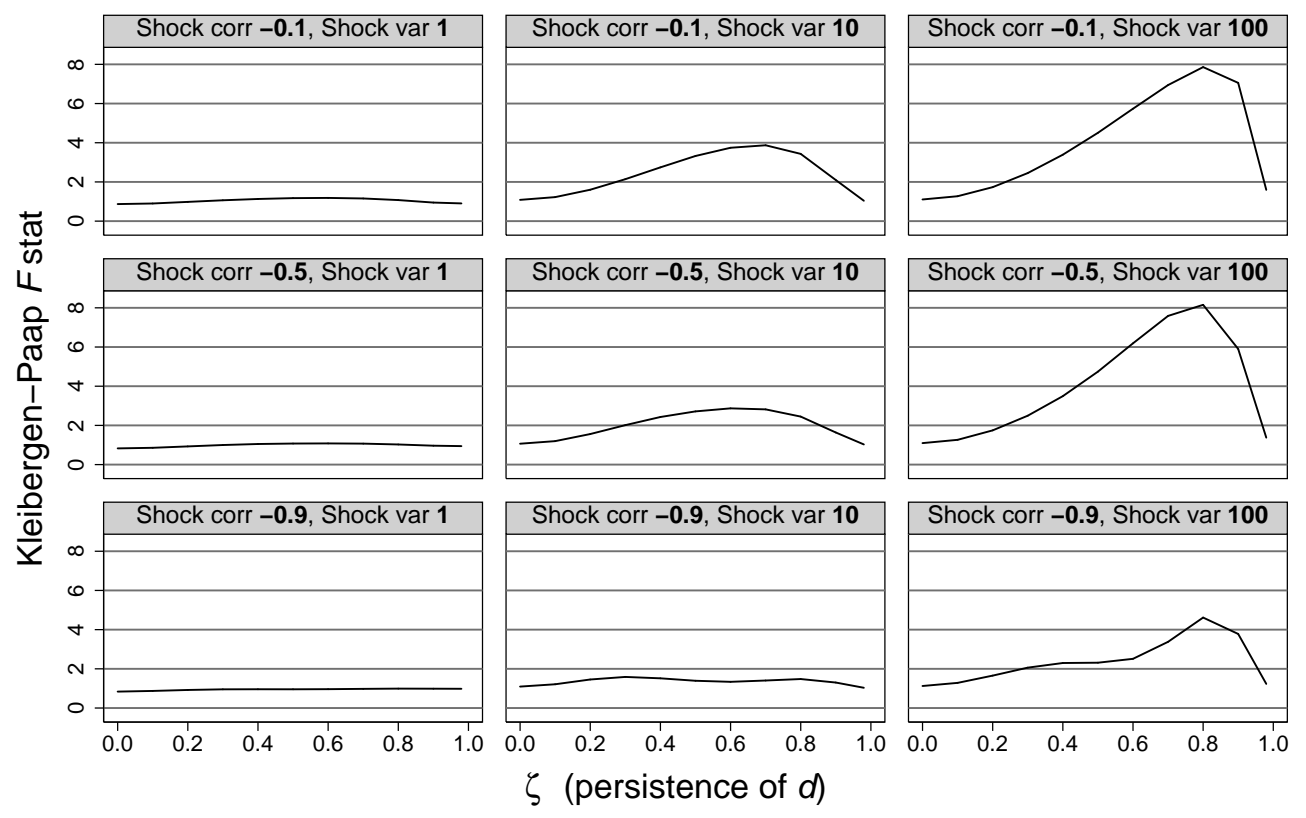

